\title{
İş Doyumu ve Çalışma Yaşamında Yalnızlık: Mersin Üniversitesi İdari Çalışanlarına İlişkin Bir Araştırma ${ }^{1}$
}

\author{
Emrah KOÇAK ${ }^{2}$ ve Binali TUNÇ3
}

\section{Öz}

$\mathrm{Bu}$ araştırmada, Mersin Üniversitesi idari çalışanlarının, yalnızlık durumları ile iş doyumu düzeyleri arasındaki ilişki belirlenmeye çalışılmışır. Betimsel nicel çalışma desenine uygun olarak düzenlenen araştırmanın çalışma grubu, genel idare hizmetleri sınıfında görevli 279 katılımcıdan oluşmaktadır. Katılımcıların çalışma yaşamında yalnızlık konusundaki görüşleri, "İş Yaşamında Yalnızlık Ölçeği” ile iş doyumu konusundaki görüşleri "Minnesota İş Doyum Ölçeği” ile belirlenmiştir. Katulımcıların iş doyumu ve çalışma yaşamı yalnızlık puanlarının, bağımsız değişkenlere göre analizinde t-testi ve varyans analizi teknikleri kullanılmıştır. Katılımcıların iş doyumları ile çalışma yaşamında yalnızlık puanları arasındaki ilişki korelasyon analizi tekniği ile belirlenmiştir. Yine katılımcıların yalnızlık puanlarının, iş doyumunu yordama düzeyini belirlemek üzere regresyon analizi tekniği kullanılmıştır. Araştırma sonuçlarına göre, katılımcıların yalnızlık düzeyleri ile iş doyumları arasında ters yönlü bir ilişki bulunmaktadır. İdari çalışanların yalnızlık düzeyi arttıkça, iş doyum düzeyi düşmektedir. Erkek katılımcıların ve 20 yıldan fazla kıdeme sahip olan çalışanların, iş doyumu düzeyleri daha yüksektir. Üst unvandakilerin, astlarına göre, evli olanların, bekârlara göre, iş doyumu düzeyleri daha yüksektir. Astların amirlerine göre, duygusal yoksunluğu ve iş yaşamında yalnızlığı daha fazladır. Bekâr çalışanların, evli çalışanlara göre, yalnızlık düzeyleri daha yüksektir. Katılımcıların iş doyumu ile yalnızlık düzeyleri arasında negatif yönlü bir ilişki bulunmaktadır. Yine katılımcıların, yalnızlık düzeyleri, onların iş doyumu düzeylerinin anlamlı bir yordayıcısıdır.

Anahtar Kelimeler: İş doyumu, çalışma yaşamında yalnızlık, üniversite idari çalışanları

\section{Job Satisfaction and Loneliness in Working Life: A Study on Mersin University} Administrative Staff

\section{Abstract}

In this study, it was tried to determine the relationship between loneliness and job satisfaction levels of Mersin University administrative staff. The study group of the research consists of 279 participants. Participants' opinions about loneliness in working life, "Loneliness in Work Life Scale" and their opinions on job satisfaction were determined with "Minnesota Job Satisfaction Scale". T-test and variance analysis techniques were used to analyze the job satisfaction and work life loneliness scores of the participants. The relationship between the job satisfaction of the participants and loneliness scores in working life was determined by the correlation analysis technique. Again, regression analysis technique was used to determine the level of loneliness of the participants in their working life and the level of predicting job satisfaction. According to the results of the research, there is a negative relationship between the loneliness levels of the participants in their work life and their job satisfaction. Male participants, who have more than 20 years of seniority than women, have higher job satisfaction levels. Compared to the subordinates of the chief positions, the married ones have higher job satisfaction levels than singles. Subordinates have more emotional deprivation and loneliness in business life than their superiors. Single employees have higher levels of loneliness than married employees. There is a negative relationship between job satisfaction of the participants and their loneliness. Again, the loneliness level of the participants is a significant predictor of their job satisfaction levels.

Key Words: Job satisfaction, loneliness at work, university administrative staff

\section{Atıf İçin / Please Cite As:}

Koçak, E. ve Tunç, B. (2020). İş doyumu ve çalışma yaşamında yalnızlık: Mersin Üniversitesi idari çalışanlarına ilişkin bir araştırma. Manas Sosyal Araștırmalar Dergisi, 9(4), 2092-2112.

Geliş Tarihi / Received Date: 18.05.2020

Kabul Tarihi / Accepted Date: 25.06.2020

\footnotetext{
${ }^{1} \mathrm{Bu}$ çalışma danışmanlığı Doç. Dr. Binali TUNÇ tarafindan yürütülen yüksek lisans tezinden türetilmiştir.

2 Gazi Üniversitesi Eğitim Yönetimi Anabilim Dalı Doktora Öğrencisi, emrahkocak@mersin.edu.tr ORCID: 0000-0002-9361-820X

3 Doç. Dr. - Mersin Üniversitesi Eğitim Fakültesi, tunc75@gmail.com

ORCID: 0000-0003-3636-209X
} 


\section{Giriş}

Bu çalışmada örgütsel davranış konusundaki önemli olgulardan olan, çalışanların yalnızlık duygusu ile örgütsel iş doyumu arasındaki ilişki ele alınmaktadır. Yalnızlık, sosyal bir varlık olan insan için bireysel düzeyde olduğu kadar, örgütsel düzeyde de çeşitli sorunların göstergesidir. Çalışanlar arasında sağlıklı iletişim kanallarının oluşturulamaması çalışanların yalnızlık duygusu yaşamasının önemli nedenlerinden biridir. İnsanların sosyalleşme davranışları her ne kadar kuramsal düzeyde ayrıştırılarak incelenebilse de günlük yaşamda yalnızlık ve çalışma yaşamında yalnızlık kavramlarını birbirinden ayırmak olanaklı değildir. Çalışanlar, özel hayatlarında sağlıklı ve doyurucu sosyal ilisskiler kursalar bile, çalışma ortamında yalnızlık hissedebilmektedirler. Bu yönüyle çalışma yaşamında yalnızlık olgusu, çalışanların çalışma ortamında yaşadıkları bir duygu durumudur.

Örgütsel görev ve rol dağılımlarının, çalışanların beklenti, kapasite ve ilgileriyle uyumu önemlidir. Örgütsel yapı ve süreçler ile çalışan özellikleri uyuşmadığında, çalışanların duygu durumları zarar görürken, örgütsel çatışmalara da zemin oluşur. Bu sorunların fazlalaşması, bazı çalışanların içe kapanarak, sosyal ortamdan uzaklaşmalarına yol açabilir. Bu yönüyle araştırmada, bir devlet üniversitesindeki idari çalışanların, çalışma yaşamındaki yalnızlık durumlarının, iş doyumlarını nasıl etkilediği anlaşılmaya çalışılmaktadır.

İş doyumu, çalışanların, çalışma yaşamından beklentilerinin karşılanma düzeyini en iyi ifade eden kavramlardan biridir. İş doyumu psikolojik, fizyolojik ve çevresel etkenlerin birlikte belirleyici olduğu, bireyin yaptığ1 işle ilgili memnuniyet düzeyini gösterir (Şişman ve Turan, 2004). İş doyumu kavramı dinamik bir süreci ifade ettiğinden dolayı aynı düzeyde devamll1k göstermesi beklenemez. İş doyumu, bireyin yaşı, eğitim durumu, medeni durumu, unvanı, kıdemi ya da çalş̧ılan işin niteliği, yönetim biçimi, çalışma ortamı ve ücret politikası gibi bireysel ve örgütsel faktörlerden etkilenir. Çalışanların yalnızlık hissetmeleri, iş doyumu ve iş verimini azaltabilmektedir. Yalnızlı̆ga bağlı olarak başarı gösteremeyen çalışanların iş doyumlarının da düştüğü gözlenmektedir (Kaplan, 2011). Yalnızlık ile iş doyumu arasında negatif yönlü bir ilişkinin olduğunu öne süren araştırmalar bulunduğu gibi (Wright, 2007), iş doyumu ile sosyal ve duygusal yalnızlık olguları arasında dikkate değer düzeyde bir ilişkininin olmadığını belirten çalışmalar da bulunmaktadır (Şişman ve Turan, 2004).

Yalnızlık, insanların sosyal ilişkilerindeki yetersizlikten kaynaklanan öznel bir yaşantı durumunu ifade ederken, çalışma yaşamında yalnızlık ise örgütlerdeki sosyal ilişkiler ile ilgilidir. Üniversiteler de yükseköğretim hizmeti üreten emek yoğun örgütler olduklarından, sosyal ilişkilerin ön plana çıktı̆̆ örgütler olarak değerlendirilir. Çalışma yaşamında yalnızlık olgusu bireysel düzeyde çalışanların yaşam kalitesini azaltabileceği gibi üniversitelerde verilen eğitimin niteliğini etkilemek gibi dolaylı sonuçlara da yol açabilir. Üniversiteler gibi özel bütçeli kamu kurumlarında, idari iş ve işleyişin yürütücüsü konumundaki idari çalışanların çalışma yaşamında yalnızlık durumlarının belirlenmesi, bu bağlamda bir gerekliliktir. $\mathrm{Bu}$ araştırmanın amacı Mersin Üniversitesi idari çalışanlarının, yalnızlık duyguları ile iş doyumu düzeyleri arasındaki ilişkiyi belirlemek ve çalışanların yalnızlık durumlarının, iş doyumlarını yordama düzeyini belirlemektir.

\section{Yalnızlik}

Yalnızlık, bireyin sosyal yaşamında, yolunda gitmeyen durumlarla ilgili bir kavramdır. Yalnızlık, araştırmalara konu edilmekle birlikte sınırları tam olarak belirlenemeyen, karmaşık bir olgudur. Yalnızlık konusunda ilk kapsamlı çalısma 1875 yılında Zimmermann'ın "Yalnızlık Üzerine” (Über die Einsamkeit) isimli çalışmasıdır. Ancak konunun kavramsal gelişiminde 1950'lerde Reichmann'ın "Yalnızlık" (Loneliness) (1959) isimli çalısması milat olarak kabul edilebilir. Konu ile ilgili derinlikli deneysel çalışmalara 1980’lerde Perlman ve Peplau'nun çalışmaları öncülük etmiştir (Gierveld, Tilburg ve Dykstra, 2006).

Yalnızlık konusunda farklı disiplinlerde yapılan çalışmalar, konuyu farklı yönlerden ele almıştır. Örneğin, öncül çalışmalardan birinde Lopata (1969), yalnızlı̆̆ın hem geçmişe, hem içinde bulunulan zamana, hem de geleceğe etki edebilecek niteliğini vurgulamıstır. Yalnızlık konusunda önemli çalışmalar yapan Perlman ve Peplau (1981) yalnızlığı, bireyin sosyal ilisskiler ağında nitelik ya da nicelik anlamında hoş olmayan önemli bir eksiklik olarak tanımlamışlardır. Yine Peplau ve Perlman (1982) yalnızlık kavramının üç önemli öğesini belirtmişlerdir. Bunlardan ilki, yalnızlığın kaynağına ilişkindir. Yalnızlık bireyin sosyal ilişkilerinin yetersizliğinin bir sonucudur. İkinci öğe yalnızlı̆ın niteliğine ilişkindir. Yalnızlık öznel ve olumsuz karakterli bir deneyimdir. Öte yandan yalnızlık, başka kavramlarla da geçişken kullanılabilmekte 
veya karıştırlabilmektedir. Örneğin Korkki'ye (2012) göre yalnızlık; kimi zaman olumlu ve hatta kimi zaman hoş karşılanabilen bir durum olarak da algilanabilen "kendi başına olma" durumu veya olumsuz bir duygu durumu olan depresyonla eş anlamlı değildir. Bu bakımdan sosyal yalıtılmışlıkla eşanlamlı değildir (Gierveld, Tilburg ve Dykstra, 2006).

Yalnızlığın anlaşılmasındaki önemli güçlüklerden biri, bireylerdeki yansımalarıyla ilgilidir. Russel, Peplau ve Ferguson'un (1978) vurguladığ1 gibi yalnızlık, hoş olmayan, zaman zaman üzüntü ve 1stırap verici bir karaktere de bürünebilen ve bireyin hoşuna gitmeyen bir durumdur. Ernst ve Cacioppo’ya (1999) göre ise yalnızlık, özel ve sosyal gereksinimlerin eksikliğine tepki olarak ortaya çıkan, geçici olmakla birlikte kimi zaman süreğen olabilen, karmaşık duygular kümesidir.

Yalnızlık konusunda çalışmaların önemli bir kısmı, yalnızlığın bireyin sosyal ilişkilerinde niteliksel veya niceliksel eksikliklerden kaynaklandığı konusunda hemfikirdirler (Peplau ve Perlman, 1982). Ancak öznel ve sıklıkla da acı verici bir deneyim olabilen yalnızlığın tam olarak anlaşılamamış bir kavram olduğu da belirtilmektedir (Wright, 2005).

Yalnızlık konusunda, psikodinamik kuram, varoluşçu kuram, bilişsel kuram ve etkileşimsel kuramcılar önemli çalışmalar yürütmüşlerdir. Psikoloji ile ilgili birçok alanda olduğu gibi yalnızlık konusunda da ilk kuramsal açılamalar psikodinamik yaklaşımı benimsemiş olan Freudyen bilim insanlarından gelmiştir (Duy, 2003). Freud'a göre yalnızlık, çocukluk narsisizmi ve düşmanlıktan türemekte olup, gereksinimleri karşılanmamış olan çocuk ya yakınlık gereksinimi hisseder ya da erken dönem bağlanma figürü yoksunluğu ile yüz yüze kalır. Psikodinamik kuramlar, kişilik gelişiminin oluştuğu erken çocukluk döneminde, özellikle oral dönemde, bebeğin fizyolojik gereksinimlerini karşılayan annesine karşı geliştirdiği bağlllı̆̆ın niteliğinin, ilerleyen yaşamında önemli kişilere karşı geliştireceği duygu ve tutumlarının önemli bir belirleyicisi olduğunu kabul eder (Demir, 1990).

Varoluşçu kuramcılara göre ise yalnızlık, kendini reddetmeye yol açan bir kaygı durumudur (Wright, 2005). Varoluşçulara göre yalnızlık patolojik etkiler de barındırabilen fakat aynı zamanda bireyin öz farkındalığını da geliştiren normal bir deneyimdir. Diğer bir ifadeyle varoluşçu kuramcılar yalnızlı̆̆ın bireyler adına acı verici bir deneyim olduğunu kabul etmekle birlikte, kişinin olgunluk ve gelişimi için de gerekli olduğunu düşündükleri, bir anlamda olumlu bir yaşantı olarak değerlendirmişlerdir (Duy, 2003; Yakut, 2016). İnsanların algıları ve sosyal ilişkilerinin değerlendirilmesi ile bilişsel süreçlere vurgu yapmakta olan bilişsel kuramcılar (Peplau ve Perlman, 1982) yalnızlığın, bireyin sosyal ilişkileri ile algılanan memnuniyetsizliğinden kaynaklandığını savunurlar ve yalnızlı̆̆ı, bireyin ilişkiler hakkındaki bilişsel beklentileri doğrultusunda anlamlandırırlar (Wright, 2005). Son olarak da etkileşimsel kuramın öncülerinden Weiss'e göre yalnızlık bireyin bağlanma ve ait olma duygusuyla ilgili bir kavramdır (Yakut, 2016). Bu doğrultuda etkileşimsel kuramda yalnızlık, bireyin duygusal yakınlık hissettiği bireylerle yaşamını paylaşması olarak belirtilen "bağlanma" ile bireyin kendini, yakınlık duyduğu bir grubun parçalarından biri olarak görmesi olan "ait olma” gereksinimlerinin karşılanmadığı durumlarda yaşanan bir duygudur.

Alanyazında yalnızlık konusunda çeşitli sınıflandırmalar bulunmaktadır. Örneğin Zimmermann yalnızlığı pozitif ve negatif olmak üzere ikili biçimde sınıflandırmakta olup pozitif yalnızlık, derin düşüncelere dalmak ve meditasyon gibi amaçlar doğrultusunda bireyin kendini günlük yaşamın karmaşasından gönüllü olarak çekmesi iken, negatif yalnızlık ise kişisel ilişkilerde arzu edilmeyen bir eksiklik halidir (Akt: Gierveld, Tilburg ve Dykstra, 2006). Yalnızlık konusunda sıklıkla dikkate alınan başka bir sınıflandırmayı Weiss (1973) yapmıştır. Buna göre yalnızlık, bağlanma figürünün eksikliği ile nitelendirilen "duygusal yalnızlık" ve sosyal ilişkilerin bulunmaması ile tanımlanan "sosyal yalnızlık" olarak iki boyutludur (Akt: İmamoğlu, 2008). Peplau (1985) da yalnızlı̆ı̆n türlerine ilişkin yaptığı açıklamalarda Weiss'a göndermelerde bulunurken, duygusal yalnızlı̆g ciddi sonuçlar doğurabilen bir kavram olarak tanimlar.

Yalnızlık birey tarafindan olumsuz anlamlandırıldığında bu durumla yaşama, üstesinden gelme ve yönetme stratejileri geliştirilebilir. Ancak yalnızlık, insanların, yaşamları boyunca uzun veya kısa dönemli yaşayabilecekleri, aynı zamanda kaçınamayacakları bir duygu durumudur. Önemli nokta, yaşamın doğal bir yönüyle ilgili olan yalnızlık duygusunun, bireyin kendi iradesi dışında gelişmesidir. İlgili alanyazında yalnızlığın önlenmesinden ziyade, yönetilmesi ve kontrol altında tutulmasının önerildiğ̊ görülmektedir (Rokach ve Brock, 1998). Başka bir deyişle yaygın bir olgu haline gelen yalnızlık, diğer temel insani duygulardan biri olarak kabul edilerek yönetilmelidir. Yalnızlıkla baş etmede kimi zaman kişisel çözümler üretilirken, kimi zaman uzman psikolojik destek kaçınılmaz olmaktadır. Bazı bireyler ise sorunun çözümü konusunda girişimde bulunmak yerine herhangi bir eylemde bulunmamayı tercih etme eğilimindedirler. $\mathrm{Bu}$ 
bağlamda Peplau ve Perlman (1982) yalnızlıkla başa çıkma noktasında; bireyin mevcut sosyal ilişkilerini gözden geçirmesini, sosyal ihtiyaç ve beklentilerini değiştirmesi veya bireyin sosyal ilişkilerinin algılanan önemini azaltarak kurduğu sosyal ilişkilerden edindiği doyumu arttırmayı önermektedirler.

\section{Çalı̧̧ma Yaşamında Yalnızlık}

Bireyin sosyal uyumunu bozan ve yaşamını zorlaştıran yalnızlık olgusu, çalışma yaşamında da sıklıkla dile getirilmektedir. Sosyal ilişkiler, yaşamın farklı alanlarına göre değişkenlik gösterebilmektedir. Kimi zaman günlük yaşamında sağlıklı ilişkiler kurabilen bireyler, çalışma yaşamında aynı düzeyde ilişkiler kurmada zorlanabilmektedirler. Çalışma yaşamında yalnızlık olgusu, genel yaşantıdaki yalnızlık durumuyla ilgili olmakla birlikte, çalışma yaşamının dinamikleriyle yakından ilgilidir.

Örgütsel başarıyı etkileyebilecek etmenlerden biri de örgütlerdeki sosyal ilişkilerin niteliğidir. Çalışanların bireysel olduğu kadar diğer çalışanlara ilişkin alg1 ve tutumları, örgütsel ilişkileri etkilemektedir. $\mathrm{Bu}$ nedenle giderek artan sayıda araştırmacı, çalışma yaşamında yalnızlık konusuyla ilgilenmektedir. Yalnızlı̆̆n, genelde, bireyin kişiliğindeki sosyal yetersizlik olarak düşünülmesi ve bireylerin kişiliğine aşırı vurgu yapılarak, kişilikten kaynaklanan eksiklikler ile ilişkilendirilmesi (Wright, 2005), çevresel etmenlerin ve özellikle de örgütsel çevrenin ihmal edilmesine yol açmışır. Çalışma yaşamında yalnızlık, genel anlamda yalnızlık olgusunun aksine, çalışma ortamında gerçekleşmektedir (Doğan, Çetin ve Sungur, 2009; Mercan, Oyur, Alamur, Gül ve Bengül, 2012). Yilmaz ve Aslan’a (2013) göre yalnızlık bireysel özelliklerden kaynaklı iken, çalışma yaşamında yalnızlık, daha çok sosyal çevreden kaynaklanan yalıtılmışlık ve kendi başına olma durumudur. Korkki'ye (2012) göre insani bir durum olmasından dolayı bireysel bir sorun olarak algılanan çalışma yaşamında yalnızlık, yöneticiler tarafından örgütün bütününü ilgilendiren bir durum olarak görülmelidir.

Çalışma yaşamında yalnızlık olgusunu, "bireyselleşme" süreciyle de ilişskilendiren çalışmalar çoğalmaktadır. Bireyselleşmenin giderek artmasıyla bağlantılı olarak, çalışma yaşamında rekabet kültürünün yaygınlaşması, çalsşanlar arasında dayanışmayı ve etkileşimi olumsuz etkilemektedir. Kişisel başarının, bireysel anlamda bağımsız olmayla erişilebilecek bir düzey olduğu vurgulanmaktadır. Bu durum temel insan ihtiyaçlarından "ait olma, topluluk halinde yaşama ve dayanışma" olgularıla çelişebilmektedir. Benzer biçimde Peplau ve Perlman (1982) da rekabetçi koşulların yol açtı̆ı bireysellik ve bu sayede elde edilen başarının yalnızlı̆ga neden olabileceğini vurgulamaktadırlar.

Örgütsel değiş̧kenler kadar, yaş, medeni durum, eğitim düzeyi ve cinsiyet gibi bireysel etmenler, çalışma yaşamında yalnızlı̆ı da etkilemektedir (Karaduman, 2013). Bununla birlikte kişilik özellikleri (Çetin ve Alacalar, 2016) ve yapılan işin niteliği de çalışma yaşamında yalnızlı̆̆ etkilemektedir (Kaplan, 2011). Ayrıca yalnızlık ile sosyal destek, işin yalnız yapılması, olumsuz örgüt iklimi, çalışanlar arasındaki ilişkiler ve sorunlar gibi çok çeşitli etmenlerden etkilenebilmektedir (Oğuz ve Kalkan, 2014; Tabancalı ve Korumaz, 2014; Yılmaz ve Aslan, 2013). Psikolojik yönden ise duygusal zekâ ve psikolojik sermayenin de çalışma yaşamında yalnızlık üzerinde etkisi tartışılmaktadır (Mercan vd., 2012). Genel olarak yalnızlık, akla gelebilecek pek çok örgütsel ve bireysel öge ile ilişkili değerlendirilebilen bir olgudur.

Çalışma yaşamında yalnızlık olgusu ile ilgili bir diğer nokta, yalnızlık duygusuyla baş etme durumlarıdır. Çalışanlar arası olumsuz ilişkiler, kaygı düzeyinin artması, depresyon, zihinsel bozukluklar, dolaşım sistemi rahatsızlıkları, hatta intihara teşebbüs gibi ciddi sonuçlar doğurabilmektedir. Bazı çalışanlar deneyimledikleri bu duruma karşı içe kapanmayı tercih ederken bazıları ise ortaya çıkan gerilim, kaygı ve öfke gibi duyguları açığa vurmayı seçebilirler. Bu bağlamda Korkki (2012) çalışma yaşamında yalnızlık ile başa çıkma yöntemleri arasında çalışanların günlük sohbetler için birbirlerine ve dolayısıyla kendilerine zaman ayırmalarını, işle ilgili konularda yardım isteme ve yardım önermelerini, yöneticilerin ise molalardan rahatsız olmamalarını, bu gibi durumların insanların daha yoğun çalışmalarını sağladığını ifade etmektedir.

Çalışma yaşamında yalnızlık, üzerinde fazla durulmamış bir kavramdır. Wright (2005), çalışma yaşamında yalnızlığın hem uygulamada hem de kuramsal yönlerden sınırlı düzeyde ele alınması ve belirsizlikler taşıyan bir yapıya sahip olmasından kaynaklandığını belirtir. Bireylerin, zamanlarının belki de en büyük bölümünü geçirdikleri çalışma yaşamında yalnızlık konusunun, Türkçe alanyazında daha fazla ihmal edildiği söylenebilir. Başka bir deyişle konu ile ilgili alanyazın büyük ölçüde yabancı dildeki araştırmalardan oluşmaktadır. Bu bağlamda Gumpert ve Boyd'un (1984) çalışması, yalnızlı̆̆ın "başı başına zor bir durum" ve "çalışanların büyük bir gerilim altında olmalarına neden" olan bir durum olarak ortaya koydukları çalışmaları önemli katkılar sunmuştur. Wright (2007) da benzer biçimde çalışma yaşamı yalnızlığının çalışanlarda stres yaratan, çalışan tutumları üzerinde olumsuz etkide bulunan, örgütsel 
bağıllığın düşük olmasına ve örgütten ayrılma isteğinin artmasına yol açan bir etmen olduğu sonucuna varmıştır. Bununla birlikte çalışma yaşamında yalnızlı̆ın, örgütsel güven davranışı (Kaplan, 2011), örgütsel destek (Karakurt, 2012), sosyal destek (Oğuz ve Kalkan, 2014), işe bağlllık ve örgütsel bağlllık ile negatif yönlü (Lam ve Lau, 2012) ilişkisi olduğu belirlenmiştir. Ayrıca bu olgunun akademisyenlerin işten ayrılma niyetlerini artırdığı belirlenirken (Demirbaş, 2016), çalışma yaşamında yalnızlık yaşayan bireylerin, yaratıcllık düzeylerinin düşük olduğuna ilişkin bazı bulgulara da ulaşılmıştır (Peng, Chen, Xia ve Ran, 2017).

\section{Çalışanların İş Doyumu}

İş doyumu, 20. yüzyllın başlarında gündeme gelmeye başlamış ve dünya savaşları sonrasında yoğun ilgi gören bir olgudur. McCann'in (2001) 21. yüzyllın başına gelindiğinde, iş doyumu konusunda yapılan çalışmaların sayısının beş bini geçtiğini belirtmesi, konunun genişliğinin ve öneminin bir göstergesi olarak kabul edilebilir. Doğal olarak bu durum iş doyumu konusunun tanımlanması ve anlaşılması konusundaki görüş farklılıklarının da göstergesidir. Örneğin Hellman (1997) iş doyumunu, bireyin çalışmakta olduğu örgütten aldıkları ile almak istedikleri arasındaki farklılıkların neden olduğu, duygusal ve bilişsel tepkiler olarak tanımlar. Öyle ki iş doyumu, çalışanların işe devam kararının önemli belirleyicilerinden biridir. Martin ve Schinke (1998) ise iş doyumunu, bireyin iş yaşamı ile ilgili değerlendirmeleri sonucu elde ettiği olumlu duyguların derecesi olarak tanımlarken, işe gelmeme ve işi bırakma oranlarıyla tutarlı ilişkiyi vurgulamıstır.

İş doyumu, örgütsel amaçlar ve çalışanların amaçlarının örtüşmesi ile bağlantılı bir olgudur. Örgütsel üretimin çalışanların bireysel üretimine bağlı olduğundan hareketle, çalışanların emeklerine karşlık maddi ve sosyo-psikolojik beklentilerinin olması doğal bir durumdur. Başka bir ifadeyle çalışma yaşamı örgüt ve çalışan bağlamında karş1ılklı bir var olma ilişkisi içinde gerçekleşir. Bu da iş doyumunun örgütsel devamlılık açısından olduğu kadar, çalışanların bedensel ve duygusal sağlığı açısından önemini gösterir.

İş doyumuna ilişkin kuramsal çalışmalar, Hawthorne araştırmalarına dayandırılabilitr. Çalışanı ekonomik insana (homo-economicus) ve örgütsel verimlilik artışının mekanik ögelerinden birine indirgeyen klasik yönetim anlayışı yerine, onların birey olarak da ele alındığı ve değer verildiği insan ilişkileri yaklaşımının ortaya çıkışı, iş doyumu kavramının tam olarak kuramsallaştırılamamış olsa bile başlangıç noktası olarak değerlendirilebilir (Çelik, 1987). Bu dönüşüm çalışanları neyin güdülediğini anlamaya dönük kuramsal çalışmaların yapılmasına öncülük etmiştir. Bu yönüyle örgütsel güdülenmeyi ele alan çalıssmaların, iş doyumunu anlamaya yönelik çalışmaların gelişimine önemli katkısı olduğu söylenebilir.

İş doyumu "bireysel" ve "örgütsel" birçok değişkenden etkilenir. Bireysel etkenler, bireyin demografik, bedensel, duygusal ve sosyal-çevresel özellikleriyle ilgilidir. Örgütsel etkenler ise çalışanın dışında meslek alanı ve örgüt içi çalışma koşullarıyla ilgili özelliklerdir. Bunlar başarı, saygınlık, tanınma gibi meslek alanı ile ilişkili etkenler olabileceği gibi, işin niteliği, çalışma koşullanı, yönetim yapısı, maddi özlük hakları, takdir edilme ve kariyer olanakları, çalışma arkadaşları arası ilişkiler gibi çalışılan örgüte ilişkin etkenlerdir (Agaoğlu, 2011; Parsak, 2010; Yıldız, 2010).

\section{Çalışma Yaşamında Yalnızlık ve İş Doyumu İlişkisi}

Çalışma yaşamında yalnızlık olgusunun, çalışanların tutum ve davranışlarını etkileme düzeyi ile ilgili alanyazın oldukça sınırlıdır. Çalışma yaşamında yalnızlığın birey ve örgüt düzeyindeki etkilerini anlamak kimi açılardan önem göstermektedir. Sosyal ilişkilerden dışlanmış bir çalışanın edimi (performansı) ve örgütsel bağlılığı düşecektir. Çalışanın ediminin düşmesi başarısızlık duygusuna yol açarak, iş doyumu düzeyini düşürmektedir (Mercan vd., 2012; Wright, 2005). Keser ve Karaduman da (2014), çalışma yaşamında yalnızlığın çalışanlar üzerindeki etkilerinin başında, iş doyumunun düşmesinin geldiğini belirtirler. Yalnızlık hisseden çalışanlarda, özgüven kaybı ve yetersizlik duygusunda artış gözlenirken, iş doyumunda düşüşler gözlenmektedir. Kaymaz, Eroğlu ve Sayılar’a (2014) göre ise çalışma yaşamında yalnızlık duygusunun artması zincirleme reaksiyon sonunda, iş doyumu düşüklügü ve işi bırakmaya kadar varabilmektedir. Benzer şekilde Tabancalı da (2016) çalışma yaşamında yalnızlık yaşayan çalışanların özgüven sorunu yaşamalarının, kendilerini yetersiz görmelerinin ve başarıya olan inançlarını kaybetmelerinin iş doyumunu düşüreceğini belirlemiştir. Aksu (2012) çalışanların salt ekonomik gereksinimlerini karşılamak için değil, kişisel ve sosyal gereksinimlerini de karşılamak amacıyla çalıştıklarını vurgulamaktadır. Dolayısıyla çalışanların iş doyumu düzeyleri ile çalışma yaşamında yalnızlık yaşama durumları arasında bir nedensellik olduğu da düşünülebilir. İs doyumu azaldıça çalışma yaşamında yalnızlık düzeyi artarken, yalnızlık düzeyi azaldıkça işdoyumu düzeyi artmaktadır (Kılıç ve Gümüşeli, 2010). Genel 
olarak alanyazındaki tartışmalar çalışma yaşamında yalnızlık olgusunun iş doyumunu etkileyerek, hem çalışan hem de örgütler için istenmeyen sonuçlara yol açabildiğini göstermektedir.

\section{Yöntem}

$\mathrm{Bu}$ araştırma Mersin Üniversitesi’nde görevli idari çalışanların yalnızlık ve iş doyumu düzeyleri arasındaki ilişkiyi belirlemeyi amaçlamaktadır. Bu bakımdan çalışma ilişkisel tarama modeline uygun desenlenmiştir. Araştırmada idari çalışanların çalışma yaşamında yaşadıkları yalnızlık düzeyi ile iş doyumları arasındaki ilişki niceliksel betimlemelere dayalı olarak belirlenmiştir.

\section{Çalışma Grubu}

Araştırmanın çalışma grubu Mersin Üniversitesi'nde görev yapan genel idare hizmetleri sınıfindaki 279 idari çalışandan oluşmaktadır. Genel idare hizmetleri sınıfı 657 sayılı Devlet Memurları Kanunu'nda "Kanunun kapsamına dâhil kurumlarda yönetim, icra, büro ve benzeri hizmetleri gören ve bu Kanunla tespit edilen diğer sınıflara girmeyen memurlar Genel İdare Hizmetleri sınıfını teşkil eder." şeklinde tanımlanmaktadır. Katılımcıların sosyo-demografik değişkenlerine ilişkin bilgiler, Tablo 1'de yer almaktadir.

Tablo 1. Katılımolara İlişkin Kişisel Bilgiler

\begin{tabular}{|c|c|c|c|}
\hline Değişken & Düzey & $n$ & $\%$ \\
\hline \multirow{2}{*}{ Cinsiyet } & Kadın & 127 & 45,5 \\
\hline & Erkek & 152 & 54,5 \\
\hline \multirow{4}{*}{ Yaş } & $20-30$ & 33 & 11,8 \\
\hline & $31-40$ & 114 & 40,9 \\
\hline & $41-50$ & 95 & 34,0 \\
\hline & 51 ve üzeri & 37 & 13,3 \\
\hline \multirow{3}{*}{ Kidem } & $0-9 Y_{11}$ & 81 & 29,1 \\
\hline & 10-19 Yil & 93 & 33,3 \\
\hline & $20 Y_{1} l$ ve üzeri & 105 & 37,6 \\
\hline \multirow{2}{*}{ Medeni Durum* } & Evli & 207 & 74,2 \\
\hline & Bekâr & 71 & 25,4 \\
\hline \multirow{2}{*}{ Unvan } & Amir & 55 & 19,7 \\
\hline & Memur & 224 & 80,3 \\
\hline Toplam & & 279 & 100,0 \\
\hline
\end{tabular}

Tablo 1'e göre katılımcıların \%45,5’i kadın (127 çalışan), \%54,5’i erkek (152 çalışan), \%11,8’i 20-30 yaş (33 çalışan), \%40,9’u 31-40 yaş (114 çalışan), \% 34,0’i 41-50 yaş (95 çalışan), \% 13,3’ü 51 ve üzeri (37 çalışan) yaşlardadır. Katılımcıların \%29’u 0-9 yıl (81 çalışan); \%33,3’ü 10-19 yıl (93 çalışan) ve \%37,6’sı ise 20 yıldan fazla (105 çalışan) kıdeme sahiptir. Bununla birlikte katılımcıların \%74,2'si evli (207 çalışan), \% 25,4'ü bekârdır (71 çalışan). Katılımcılanın \%19,7'si daire başkanı, şube müdürü, fakülte/yüksekokul sekreteri ve şef kadrolarındaki kişilerden oluşan yöneticiler (55 çalışan); \%80,3’ü ise daha alt pozisyonlardaki çalışanlardır (224 çalışan).

\section{Veri Toplama Araçları}

Araştırma verileri üç bölümden oluşan bir araçla elde edilmiştir. Birinci bölümde katıllımcıların kişisel bilgileri (cinsiyet, yaş, kıdem, medeni durum ve unvan), ikinci bölümde "İ̧̧ Yaşamında yalnızlık Ölçeği” ve üçüncü bölümde "Minnesota İş Doyum Ölçeği” yer almıştır.

İs Yaşamında Yalnızlık Ölçeğgi: Katılımcıların çalışma yaşamında yalnızlık düzeylerini belirlemek amaciyla, Wright, Burt ve Strongman (2006) tarafindan geliştirilen, Doğan, Çetin ve Sungur (2009) tarafindan Türkçeye uyarlanan “İş Yaşamında Yalnızlık Ölçeği” [İYYÖ] kullanılmıştır. IYYYÖ’nün, özgün formu 7 basamaklı Likert tipi ölçek modeline göre düzenlenmiştir. Ancak Türk dili açısından en çok 5 seçeneğe kadar açık ve anlaşılır ifadeler yazılabileceği düşüncesiyle (Şeker ve Gençdoğan, 2006, Akt: Doğan vd., 2009) Türkçe formu 5'li Likert türüne uygun tasarlanmıştır. IYYYÖ, "Duygusal Yoksunluk" (1, 2, 3, 4, 5, 6, 7, 8 ve 9'uncu maddeler) ve "Sosyal Arkadaşlık" (10,11, 12, 13, 14, 15 ve 16'ncı maddeler) olmak üzere iki boyutlu ve 16 maddeden oluşmaktadır. Ölçeğin 5, 6, 10, 11, 12, 14, 15 ve 16 'ncı maddeleri ters puanlanmaktadır. Ölçek puanlarının yükselmesi, iş yaşamında yalnızlık duygusunun derecesinin yükseldiğini göstermektedir. IYYÖ’nün Türkçe formunun bütünü için iç tutarllk katsayıs1 .90, "Duygusal Yoksunluk" boyutu için .87 ve "Sosyal Arkadaşlık" boyutu için .83 olarak belirlenmiştir (Doğan vd., 2009). 
Katılımcılar görüşlerini, "Hiç Katılmıyorum", "Katılmıyorum”, "Kararsızım”, "Katıllyorum" ve "Tamamen Katılıyorum" ulamlanndan biriyle belirtmişlerdir.

Minnesota IşS Doyum Ölçeği: Katılımcıların iş doyumu düzeylerini belirlemek üzere Weiss, Dawis, England ve Lofquist (1967) tarafindan geliştirilen ve Baycan (1985) tarafindan Türkçeye uyarlanan "Minnesota İş Doyum Ölçeği" [MIDÖ] kullanılmıştır. MIDÖ 20 maddeden oluşan beşli Likert türü bir ölçektir. Ölçek, "İçsel Doyum" (1, 2, 3, 4, 7, 8, 9, 10, 11, 15, 19 ve 20'nci maddeler) ve "Dişsal Doyum" (5, 6, 12, 13, 14, 16, 17 ve 18 'inci maddeler) olmak üzere iki boyut ve 20 maddeden oluşmaktadır. İçsel doyum puanı, başarı, işin niteliği, tanınırlık, manevi haz gibi kişisel memnuniyeti; dıssal doyum puanlanı, üstlerin astlarına karşı yaklaşımının objektifliği, üstlerin karar verme noktasında inisiyatif alabilme durumları, elde edilen kazanç, kariyer olanakları ve çalışma koşulları gibi çalışma koşullarına ilişkin memnuniyetin düzeyini göstermektedir. Ölçekten alınabilecek en yüksek puan 100, en düşük puan 20 olup, puanların 20'ye yaklaşması doyum düzeyinin düştüğünü, 100'e yakın olması ise doyum düzeyinin yükseldiğini göstermektedir (Gündüz, Çapri ve Gökçakan, 2013; Sayg1lı ve Çelik, 2011). Katılımcılar görüşlerini "Hiç Memnun Değilim", "Biraz Memnunum", Orta Düzeyde Memnunum", "Memnunum" ve "Çok Memnunum" ulamlarnndan biriyle belirtmişlerdir.

Çalışmada veri toplama araçlarının kullanım izni ve Mersin Üniversitesi idari çalışanlarına uygulama izinleri alınmıştır. Veri toplama araçları araştırmacılarca yüzyüze uygulanmış, katıllımcılara araştırmanın amacı açıklanmış ve gönüllülük beyanı istenmiştir.

\section{Verilerin Analizi}

Verilerin analizinde, dağılımın normallik varsayımının karşılanıp karşılanmadığı basıklık ve çarpıklık katsaylları hesaplanarak belirlenmiştir. Tabachnick ve Fidell'in (2013) normal dağılım için belirledikleri aralıklar (-1.5 ile +1.5) gözönünde bulundurulduğunda; bu çalışmada elde edilen basıklık ve çarpıklık değerlerinin kabul aralıklanı içinde olduğu görülmüştür. Araştırmada katılımcıların iş doyumu ve iş yaşamında yalnızlık puanlarını betimlemek için frekans, yüzde ve ortalama istatistikleri kullanılmıştır. Verilerin dağılımı normallik özelliği gösterdiğinden, katılımcıların puanlarının cinsiyet, medeni durum, unvan ve kıdem değişkenlerine göre anlamlı düzeyde farklılık gösterip göstermediği, ortalamalar arası farkın anlamlılık testleri olan t-testi ve ANOVA testi ile belirlenmiştir. Katılımcıların iş doyumu puanları ile çalışma yaşamında yalnızlık puanlanı arasındaki ilişki korelasyon analizi tekniği ile, yine katılımcıların yalnızlık düzeylerinin, iş doyumunu ne düzeyde yordadığını belirlemek üzere regresyon analizi tekniği kullanılmıştır. Bulguların yorumlanmasında $\mathrm{p}<.05$ anlamlılık düzeyi esas alınmıştır.

\section{Bulgular}

Bu bölümde araştırmanın amaçları doğrultusunda yapılmış olan istatistiksel analizlerden elde edilen bulgulara yer verilmektedir.

\section{Katılımcıların iş doyumu düzeyine ilişkin bulgular}

Katılımciların MİÖ̈ içsel doyum boyutunda ortalama ve standart sapma puanları Tablo 2'de yer almaktadir.

Tablo 2. Katılimclarm MIDÖ İssel Doyum Alt Boyutuna İlişkin Görüsleri

\begin{tabular}{|c|c|c|c|}
\hline Maddeler & $N$ & $A O$ & $s d$ \\
\hline 1. $\quad$ Sürekli bir șeylerle meşgul olma olanağı & 279 & 3,64 & 1,063 \\
\hline 2. Tek basıına calısma olanağı & 279 & 3,42 & 1,184 \\
\hline 3. Zaman zaman farklı șeyler yapabilme olanağı & 279 & 3,49 & 1,120 \\
\hline 4. Toplumda bir yer edinme olanağı & 279 & 3,50 & 1,059 \\
\hline 5. Vicdanıma ters düşmeyen șeyleri yapabilme olanağı & 279 & 3,77 & 1,066 \\
\hline 6. Sürekli bir işe sahip olma olanağı & 279 & 4,09 & 974 \\
\hline Başkaları için bir şeyler yapabilme olanağı & 279 & 3,87 & 1,021 \\
\hline Başkalarına ne yapacaklarını söyleme olanağı & 279 & 3,43 & 1,123 \\
\hline 9. Yeteneklerini kullanabilme olană̆1 & 279 & 3,39 & 1,218 \\
\hline 10. Kendi kararını verme özgürlüğ̈̈ & 279 & 3,07 & 1,224 \\
\hline 11. İşsinden elde ettiği başarı duygusu & 279 & 3,62 & 1,099 \\
\hline
\end{tabular}

Tablo 2'ye göre katıllımc1lar en yüksek düzeyde "Sürekli bir işe sabip olma olană̆g" (AO=4,09) maddesine katılmaktadırlar. Bunu "Basskalar için bir şeyler yapabilme olanağı" ( $\mathrm{AO}=3,87)$ ve "Vicdamma ters düsmeyen seyleri yapabilme olanăğ" ( $\mathrm{AO}=3,77)$ maddeleri izlemektedir. Buna göre katılımcıların iş doyumlarını en fazla 
etkileyen etken, kadro güvencesidir. Ayrıca katılımcılar başkaları için bir şeyler yapma ve vicdanına ters düşmeyen şeyler yapmayı iş doyumu açısından diğer maddelerden daha önemli görmektedirler.

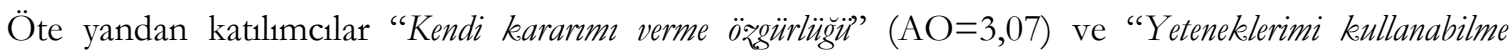
olanağı" ( $\mathrm{AO}=3,39)$ maddelerine görece düşük düzeyde katılmaktadırlar. Buna göre katılımcıların kendilerini karar vermede özgür hissetmede sorunlar yaşadıkları ve çalışma yaşamları süresince karar verme yetkisi kullanabilme noktasında istedikleri seviyeye gelemedikleri söylenebilir. Özellikle katılımcıların kendi kararlarını verme konusundaki düşünceleri, tek başına içsel doyum alt boyutunda elde edilmiş olan puan ortalamasını aşağı çekmekte, başka bir deyişle içsel doyum düzeyini düşürmektedir.

Tüm ortalamalar dikkate alındığında ise katılımcıların ifadelere orta ve üzeri düzeyde katıldıkları görülmektedir. $\mathrm{Bu} \mathrm{da}$, katılımcıların iş doyumlarının ortanın üzerinde olduğunu göstermektedir. Katılımcıların MIDÖ'nün dışsal doyum boyutunda ortalama, sıra ve standart sapma puanları Tablo 3'te yer almaktadır.

Tablo 3. Katıllmollarn MIDÖ Dışsal Doyum Alt Boyutuna Ilişkkin Görüsleri

\begin{tabular}{|c|c|c|c|}
\hline Maddeler & $N$ & $A O$ & $s d$ \\
\hline 12. Yöneticinin, elemanlarına karşı davranış tarzı & 279 & 3,76 & 1,032 \\
\hline 13. Yöneticinin karar verme konusundaki yeterliliği & 279 & 3,70 & 1,086 \\
\hline 14. Kurum politikasını uygulama olanağı & 279 & 3,11 & 1,131 \\
\hline 15. Aldığı ücret & 279 & 2,70 & 1,256 \\
\hline 16. Bu işte ilerleme olanağı & 279 & 2,44 & 1,365 \\
\hline 17. İş yaparken kendi yöntemlerini deneme olanağ1 & 279 & 3,31 & 1,202 \\
\hline 18. Calıșma koșulları & 279 & 3,22 & 1,144 \\
\hline 19. Çalışma arkadaşlarımın birbiriyle anlaşması & 279 & 3,51 & 1,150 \\
\hline 20. Yaptığ1 ivi bir iș karșllı̆ında aldığı övgü & 279 & 3,31 & 1,216 \\
\hline
\end{tabular}

Tablo 3'e göre katılımcıların en yüksek düzeyde katıldıkları ifade "Yöneticinin elemanlarna karşı davranıs tarz?" maddesidir $(\mathrm{AO}=3,76)$. Benzer şekilde yöneticilerin karar verme konusundaki yeterliklerinin değerlendirildiği maddeye verilen yanıtlarda da katılımclların memnuniyeti göze çarpmaktadır $(\mathrm{AO}=3,70)$. Katılımcıların, bu boyuttaki puanları iki düzeyli sınıflandırılabilir: " $B$ u iste ilerleme olanağð”" $(\mathrm{AO}=2,44)$ ve "Aldiğr ü̈ret" (AO=2,70) maddelerine ilişkin puanlar, diğer maddelerin puanlanna göre düşüktür. Diğer maddelere verilen yanıtların ortalamaları $(\mathrm{AO}=3,11)$ ile $(\mathrm{AO}=3,76)$ arasında yer almaktadır.

Katılımcıların iş doyumu puanlarının cinsiyete göre dağılımı, Tablo 4'te yer almaktadır.

Tablo 4. Katılımoların Cinsiyetine Göre $\dot{I}_{3}$ Doyumuna Iliş̧kin Puanlarmın T-testi Sonuclar

\begin{tabular}{|c|c|c|c|c|c|c|}
\hline Puanlat & Değişken & $n$ & $A O$ & $S$ & $t$ & $p$ \\
\hline \multirow{2}{*}{ İçsel Doyum } & Kadın & 127 & 3,57 & 693 & \multirow{2}{*}{,- 254} & \multirow{2}{*}{, 800} \\
\hline & Erkek & 152 & 3,59 & ,758 & & \\
\hline \multirow{2}{*}{ Dişsal Doyum } & Kadin & 127 & 3,18 & 827 & \multirow{2}{*}{,- 954} & \multirow{2}{*}{,341 } \\
\hline & Erkek & 152 & 3,27 & ,821 & & \\
\hline \multirow{2}{*}{ İş Doyumu Genel } & Kadın & 127 & 3,39 & ,716 & \multirow{2}{*}{,- 623} & \multirow{2}{*}{, 534} \\
\hline & Erkek & 152 & 3,45 & ,743 & & \\
\hline
\end{tabular}

Tablo 4'e göre içsel doyum boyutuna ilişkin puanlar, katılımcıların cinsiyetine göre anlamlı düzeyde farklılaşmamaktadır $\quad\left(\mathrm{t}_{(279)}=-0,254 ; \mathrm{p}>.05\right)$. Kadın $(\mathrm{AO}=3,57)$ ve erkek $(\mathrm{AO}=3,59)$ katılımcıların ortalamalarının çok yakın olması, kadın ve erkek katılımcıların benzer görüşlere sahip olduklarını göstermektedir.

Dışsal doyum boyutunda kadın ve erkek katılımcıların puanları arasında anlamlı fark bulunmamaktadır $\left(\mathrm{t}_{(279)}=-0,954 ; \mathrm{p}>.05\right)$. Kadın $(\mathrm{AO}=3,18)$ ve erkek $(\mathrm{AO}=3,27)$ katilımciların ortalamalarının yakın olması, dışsal doyum konusunda kadın ve erkek katılımcıların benzer görüşlere sahip olduklarını göstermektedir. İş doyumu ölçeği geneli puanları da alt boyutlarda olduğu gibi, cinsiyete göre anlamlı düzeyde farklılaşmamaktadır $\left(\mathrm{t}_{(279)}=-0,623 ; \mathrm{p}>.05\right)$.

Tablo 4'te dikkati çeken nokta, içsel ve dışsal doyum alt boyutlarına ilişkin ortalama puanların birbirinden farklılığıdır. İçsel doyum alt boyutundaki puanlar, dışsal doyum boyutu puanlarından yüksektir. $\mathrm{Bu}$ da katılımcıların içsel iş doyumlarının, dışsal doyumlarından yüksek olduğunu göstermektedir.

Katılımcıların iş doyumu düzeylerine ilişkin puanlarının kıdem değişkenine göre dağılımı Tablo 5’te yer almaktadır. 
Tablo 5'e göre katılımcıların içsel doyum alt boyutuna ilişkin puanları, kıdemlerine göre anlamlı düzeyde farklılaşmaktadır $\left(\mathrm{F}_{(2-276)}=6,111 ; \mathrm{p}<.05\right)$. Farkın kaynağına ilişkin Dunnet-C testi sonuçlarına göre; 0-9 y1l $(\mathrm{AO}=3,42)$ ve 10-19 y1l $(\mathrm{AO}=3,51)$ kıdeme sahip katılımc1ların puanları ile 20 y1l ve üzeri kıdemli $(\mathrm{AO}=3,77)$ katılımcıların puanları arasında anlamlı düzeyde fark bulunmaktadır. Bu bulgu, kıdem arttıkça, katılımcıların içsel iş doyumlarının yükseldiğini göstermektedir. Katılımcıların dışsal doyum alt boyutuna ilişkin puanlar, katılımcıların kıdemlerine göre anlamlı düzeyde farklılaşmamaktadır $\left(\mathrm{F}_{(2-276)}=2,373 ; \mathrm{p}>.05\right)$. Buna göre katılımcıların kıdemleri farklılaşsa dahi dışsal iş doyumu puanları anlamlı düzeyde farklılaşmamaktadir.

Tablo 5. Katılımolarn Kıdemlerine Göre İs Doyumuna İlişkin Puanlarmın ANOV A Sonuclar

\begin{tabular}{|c|c|c|c|c|c|c|c|c|}
\hline Puanlat & Değişken & $n$ & $A O$ & $S$ & $s d$ & $F$ & $p$ & $\begin{array}{c}\text { Anlamli Fark } \\
\text { (Dunnet-C) }\end{array}$ \\
\hline \multirow{4}{*}{$\begin{array}{l}\text { İçsel } \\
\text { Doyum }\end{array}$} & 0-9 Y1l & 81 & 3,42 & ,630 & 2 & \multirow{4}{*}{6,111} & \multirow{4}{*}{,003 } & \multirow{4}{*}{$\begin{array}{c}0-9, \quad 10-19 / \\
20+Y_{11}\end{array}$} \\
\hline & 10-19 Yil & 93 & 3,51 & 823 & 276 & & & \\
\hline & $20 Y_{11}+$ & 105 & 3,77 & 673 & & & & \\
\hline & Toplam & 279 & 3,58 & ,728 & 278 & & & \\
\hline \multirow{4}{*}{ Dişsal Doyum } & 0-9 Y1l & 81 & 3,11 & ,779 & 2 & \multirow{4}{*}{2,373} & \multirow{4}{*}{,095 } & \\
\hline & 10-19 Yil & 93 & 3,18 & 872 & 276 & & & \\
\hline & $20 \mathrm{Y}_{11}+$ & 105 & 3,36 & 802 & & & & \\
\hline & Toplam & 279 & 3,23 & 824 & 278 & & & \\
\hline \multirow{4}{*}{ İş Doyumu } & 0-9 Y1l & 81 & 3,28 & ,649 & 2 & \multirow{4}{*}{4,564} & \multirow{4}{*}{,011 } & \multirow{4}{*}{$0-9 / 20+Y_{11}$} \\
\hline & 10-19 Yil & 93 & 3,36 & 807 & 276 & & & \\
\hline & $20 Y_{11}+$ & 105 & 3,59 & 693 & & & & \\
\hline & Toplam & 279 & 3,42 & ,730 & 278 & & & \\
\hline
\end{tabular}

İş doyumunun tümü dikkate alındığında, katılımcıların puanları kıdemlerine göre anlamlı düzeyde farklılaşmaktadır $\left(\mathrm{F}_{(2-276)}=4,564 ; \mathrm{p}<.05\right)$. Farkın kaynağına ilişkin Dunnet $\mathrm{C}$ testi sonuçlarına göre; 0-9 y1l $(\mathrm{AO}=3,28)$ ile 20 yıl ve üzeri kıdemli $(\mathrm{AO}=3,59)$ katılımcıların puanları arasında anlamlı düzeyde fark bulunmaktadır. Bu sonuç içsel doyum boyutunda olduğu gibi, idari çalışanların iş doyumu düzeyinin, çalışma süresi ile doğru orantılı olarak arttı̆̆ı biçiminde yorumlanabilir.

Katılımcıların iş doyumu puanlarının unvana göre t-testi sonuçları Tablo 6'da yer almaktadır.

Tablo 6. Katılımolarn Unvanlarna Göre İs Doyumuna İliş̧ein Puanlarnın T-testi Sonuçlar

\begin{tabular}{|c|c|c|c|c|c|c|}
\hline Puanlat & Değişken & $n$ & $A O$ & $S$ & $t$ & $p$ \\
\hline \multirow{2}{*}{ İçsel Doyum } & Amir & 55 & 3,84 & 664 & \multirow{2}{*}{3,022} & \multirow{2}{*}{,003 } \\
\hline & Memur & 224 & 3,52 & ,730 & & \\
\hline \multirow{2}{*}{ Dışsal Doyum } & Amir & 55 & 3,49 & 806 & \multirow{2}{*}{2,631} & \multirow{2}{*}{, 009} \\
\hline & Memur & 224 & 3,17 & ,818 & & \\
\hline \multirow{2}{*}{ İş Doyumu } & Amir & 55 & 3,68 & ,695 & \multirow{2}{*}{2,997} & \multirow{2}{*}{, 003} \\
\hline & Memur & 224 & 3,36 & ,726 & & \\
\hline
\end{tabular}

Tablo 6’ya göre katılımcıların içsel doyum alt boyutuna ilişkin puanları, çalışılan pozisyona göre anlamlı düzeyde farklılaşmaktadır $\left(\mathrm{t}_{(279)}=3,022 ; \mathrm{p}<.05\right)$. Alt düzey görevlerdeki çalışanların içsel doyumları $(\mathrm{AO}=3,52)$, şef ve üzeri kadrolarda görev yapan mesai arkadaşlarına göre $(\mathrm{AO}=3,84)$ daha düşük düzeydedir. Dışsal doyum boyutunda da benzer biçimde amir pozisyonundaki çalışanların puanları, memur pozisyonundaki çalışanların puanlarından anlamlı düzeyde farklılaşmaktadır $\left(\mathrm{t}_{(279)}=2,631 ; \mathrm{p}<.05\right)$. Amir pozisyonundaki katılımcıların $(\mathrm{AO}=3,49)$ doyum düzeyi, astlarına $(\mathrm{AO}=3,17)$ göre, daha yüksektir.

Ölçeğin bütününde de amir pozisyonundaki katılımcıların puanları, memur pozisyonundaki katılımcılardan anlamlı biçimde farklılaşmaktadır $\left(\mathrm{t}_{(279)}=2,997 ; \mathrm{p}<.05\right)$. Ortalamalar dikkate alındığında amir pozisyonundaki katılımcıların puanları $(\mathrm{AO}=3,68)$, memur pozisyonundaki katılımcıların puanlarından $(\mathrm{AO}=3,36)$ yüksektir. Diğger bir ifadeyle ölçeğin genelinde amirlerin doyum düzeyi memurlardan daha yüksektir. Yani iş doyumu ile mesleki kariyer basamakları arasında bir ilişki bulunmaktadır.

Katılımcıların iş doyumu düzeylerine ilişkin puanlarının medeni durumlarına göre t-testi sonuçları Tablo 7'de yer almaktadır.

Tablo 7'ye göre iş doyumunun içsel doyum boyutunda evli ve bekâr idari çalışanların görüşleri anlamlı düzeyde farklılaşmaktadır $\left(\mathrm{t}_{(278)}=3,141 ; \mathrm{p}<.05\right)$. Evli çalışanların içsel doyum puanları $(\mathrm{AO}=3,66)$, bekâr 
çalışanların puanlarına $(\mathrm{AO}=3,35)$ göre daha yüksektir. Dışsal doyum boyutunda da evli katılımcıların doyum düzeyi, bekâr katılımcılara göre anlamlı düzeyde farklılaşmaktadır $\left(\mathrm{t}_{(278)}=2,477 ; \mathrm{p}<.05\right)$. Evli çalışanların iş doyumları $(\mathrm{AO}=3,30)$, bekâr çalışanların iş doyumlarından $(\mathrm{AO}=3,02)$ daha yüksektir.

Tablo 7. Katılımcılarn Medeni Durumlarna Göre İs Doyumuna İlişkin Puanlarmın T-testi Sonuçlarn

\begin{tabular}{lcccccc}
\hline Puanlar & Değissken & $\boldsymbol{n}$ & $A \boldsymbol{O}$ & $\boldsymbol{S}$ & $\boldsymbol{t}$ & $\boldsymbol{P}$ \\
\hline \multirow{2}{*}{ İçsel Doyum } & Evli & 207 & 3,66 &, 661 & \multirow{2}{*}{3,141} & \multirow{2}{*}{009} \\
\hline \multirow{2}{*}{ Dişsal Doyum } & Bekâr & 71 & 3,35 &, 863 & & \multirow{2}{*}{, 040} \\
\hline \multirow{2}{*}{ İş Doyumu Genel } & Evli & 207 & 3,30 &, 764 & \multirow{2}{*}{2,477} & \multirow{2}{*}{, 018} \\
\hline
\end{tabular}

İş doyumunun geneline ilişkin puanlar dikkate alındığında da evli ve bekâr katılımcıların iş doyum düzeyine ilişkin puanları anlamlı düzeyde farklılaşmaktadır $\left(\mathrm{t}_{(278)}=2,984 ; \mathrm{p}<.05\right)$. Evli çalışanların puanları $(\mathrm{AO}=3,50)$, bekâr çalışanların puanlarından $(\mathrm{AO}=3,20)$ yüksektir. Gerek alt boyutlarda gerekse ölçeğin tümünde, evli katılımcıların iş doyumu düzeyleri, bekâr katılımcıların iş doyum düzeylerinden yüksektir.

\section{Katılımcıların çalışma yaşamında yalnızlık düzeylerine ilişkin bulgular}

Katılımcıların çalışma yaşamında yalnızlık düzeylerine ilişkin betimsel bulgular Tablo 8'de yer almaktadir.

Tablo 8. Katılımolarn IYYÖ’nün Duygusal Yoksunluk. Alt Boyutuna Ilişkin Betimsel Sonuçlar

\begin{tabular}{|c|c|c|c|}
\hline Maddeler & $N$ & $A O$ & $s d$ \\
\hline 1. İş ortamında baskı altındayken iş arkadaşlarım tarafından yalnız bırakıldığımı hissediyorum. & 279 & 2,58 & 1,234 \\
\hline 2. Çoğunlukla iş arkadaşlarımın bana mesafeli durduklarını hissediyorum. & 279 & 2,31 & 1,083 \\
\hline 3. Birlikte çalıştı̆̆ım insanlarla arama mesafe koyduğumu hissediyorum. & 279 & 2,43 & 1,090 \\
\hline 4. Kendimi iş arkadaşlarımdan duygusal olarak uzak hissediyorum. & 279 & 2,37 & 1,091 \\
\hline 5. İş yerimdeki ilişkilerimden memnunum. & 279 & 2,18 & 0,618 \\
\hline 6. Çalıştığım iş yerinde dostluk anlayışı hâkimdir. & 279 & 2,62 & 0,685 \\
\hline 7. İş arkadaşlarımla birlikteyken çoğu zaman kendimi dışlanmış hissediyorum. & 279 & 1,99 & 0,991 \\
\hline 8. İş yerinde çoğu zaman diğer çalışanlarla birlikte aramda bir kopukluk hissediyorum. & 279 & 2,21 & 0,979 \\
\hline 9. İş yerindeyken kendimi genel bir boşluk duygusu içinde hissediyorum. & 279 & 2,17 & 1,024 \\
\hline
\end{tabular}

Tablo 8'e göre katılımcıların, duygusal yoksunluk boyutuna verdiği yanıtlar, katılmamak ve kararsız kalmak düzeylerinde yer almaktadır $(\mathrm{AO}=2,31)$. En yüksek puanı alan madde "Calıstığım işyerinde dostluk anlayış hâkimdir" olurken $(\mathrm{AO}=2,62)$, onu "Is ortaminda baskı altındayken is arkadaşarm tarafindan yalnı. burakuldı̆̆ım hissederim" maddesi izlemektedir $(\mathrm{AO}=2,58)$. Diğger yandan " $I_{s}$ s arkadaslarmla birlikteyken çŏ̆u zaman kendimi dişlanmış hissediyorum" $(\mathrm{AO}=1,99)$ ve "Is yerindeyken kendimi genel bir boşluk duygusu içinde bissederim” ( $\mathrm{AO}=2,17)$ maddelerine de katılmamak yönünde görüş bildirmişlerdir. Başka bir deyişle katılımcılar, çalıştığ1 işyerinde ilişkilerin yeterli düzeyde olduğu anlaşılmaktadır. Katılımcıların bu boyuttaki puanlarının ortalamasının, katılmamak ve kararsız kalmak arasında yer almış olması aynı zamanda katılımcıların duygusal yoksunluk yaşamadıklarına işaret etmektedir.

Katılımcıların sosyal arkadaşlık boyutundaki puanlarının betimsel dağılımları Tablo 9'da yer almaktadır.

Tablo 9. Katılımoları IYYÖ Sosyal Arkadaşlık. Alt Boyutuna İlişkin Görüsleri

\begin{tabular}{|c|c|c|c|}
\hline Maddeler & $N$ & $A O$ & $s d$ \\
\hline 10. İş yerinde sosyal ilişkilerim vardır. & 279 & 2,31 & 0,610 \\
\hline 11. İş yerimdeki sosyal etkinliklere (piknik, parti, yemek vs.) katılırım. & 279 & 2,50 & 0,619 \\
\hline 12. İş yerinde gerektiğinde işle ilgili günlük sorunlarımı konuşabileceğim biri vardır. & 279 & 2,20 & 0,607 \\
\hline 13. İş yerinde istediğimde kişisel düşüncelerimi paylaşabileceğim kimse yoktur. & 279 & 2,28 & 1,115 \\
\hline 14. İş yerinde mola zamanlarında beraber vakit geçirebileceğim biri vardır. & 279 & 2,16 & 0,589 \\
\hline 15. Kendimi iş yerindeki arkadaş grubunun bir parçası olarak hissederim. & 279 & 2,26 & 0,651 \\
\hline 16. İş yerinde beni dinleme zahmetinde bulunan insanlar vardır. & 279 & 2,14 & 0,632 \\
\hline
\end{tabular}

Tablo 9'a göre katılımcilann "İs yerimdeki sosyal etkinliklere (piknik, parti, yemek vs.) katıllrm” maddesine ilişkin puanlarının ortalaması katılmamak ile kararsız kalmak arasındadır (AO=2,50). Bunu "İs yerinde sosyal ilişkilerim vardir" maddesine ilişkin puanlar izlemektedir $(\mathrm{AO}=2,31)$. Ayrıca "Is yerinde beni dinleme zahmetinde bulunan insanlar vardir" (AO=2,14) ve "Is yerinde mola zamanlarnda beraber vakit gecirebileceğim biri vardır" $(\mathrm{AO}=2,16)$ maddelerine yüksek düzeyde katılmadıklanını bildirmişlerdir. IYYÖ’nün sosyal arkadaşlık alt 
boyutu ortalamaları, katılımcıların sosyal arkadaşlık yaşama, çalışma ortamında bir arada vakit geçirebilecekleri, birbirlerinin gerek iş yeri ile gerek iş yeri dışındaki yaşamlarıyla alakalı sorunlarını dinleyebilecekleri düzeyde diyalog kurabilecekleri ilişkilerinin görece sınırlı olduğunu göstermektedir.

Katılımcıların çalışma yaşamında yalnızlık düzeylerine ilişkin puanlarının cinsiyete göre t-testi sonuçları Tablo 10'da yer almaktadır.

Tablo 10. Katılımolarn Cinsiyetlerine Göre İs Yaşamında Yalnızlğga İlişkin Puanlarnmn T-testi Sonuclar

\begin{tabular}{|c|c|c|c|c|c|c|}
\hline Puanlat & Değişken & $n$ & $A O$ & $S$ & $t$ & $p$ \\
\hline \multirow{2}{*}{ Duygusal Yoksunluk } & Kadın & 127 & 2,24 & ,772 & \multirow{2}{*}{$-1,364$} & \multirow{2}{*}{,174 } \\
\hline & Erkek & 152 & 2,37 &, 765 & & \\
\hline \multirow{2}{*}{ Sosyal Arkadaşlık } & Kadin & 127 & 2,21 & ,789 & \multirow{2}{*}{$-1,020$} & \multirow{2}{*}{, 308} \\
\hline & Erkek & 152 & 2,31 & ,738 & & \\
\hline \multirow{2}{*}{ İş Yaşamında Yalnızlık } & Kadin & 127 & 2,23 & ,729 & \multirow{2}{*}{$-1,333$} & \multirow{2}{*}{,184 } \\
\hline & Erkek & 152 & 2,34 & ,669 & & \\
\hline
\end{tabular}

Tablo 10'a göre duygusal yoksunluk boyutuna ilişkin kadın ve erkek çalışanların puanları anlamlı düzeyde farklılaşmamaktadır $\left(\mathrm{t}_{(279)}=-1,364 ; \mathrm{p}>.05\right)$. Sosyal arkadaşlık boyutu puanları da cinsiyete göre anlamlı düzeyde farklılaşmamaktadır $\left(\mathrm{t}_{(279)}=-1,020 ; \mathrm{p}>.05\right)$. Ölçeğin geneli için de katılımcıların puanları cinsiyetlerine göre anlamlı düzeyde farklılaşmamaktadır $\left(\mathrm{t}_{(279)}=-1,333 ; \mathrm{p}>.05\right)$.

Katılımcıların yalnızlık puanlarının kıdemlerine göre ANOVA testi sonuçları Tablo 11'de yer almaktadir.

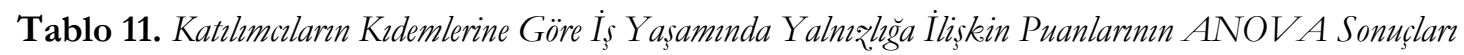

\begin{tabular}{|c|c|c|c|c|c|c|c|}
\hline Puanlar & Değisken & $n$ & $A O$ & $S$ & $s d$ & $F$ & $p$ \\
\hline \multirow{4}{*}{$\begin{array}{l}\text { Duygusal } \\
\text { Yoksunluk }\end{array}$} & $0-9$ Yil & 81 & 2,30 & ,792 & 2 & \multirow{4}{*}{,634 } & \multirow{4}{*}{, 531} \\
\hline & 10-14 Y1l & 93 & 2,38 & ,785 & 276 & & \\
\hline & $20 Y_{11}+$ & 105 & 2,26 & ,740 & & & \\
\hline & Toplam & 279 & 2,31 & ,770 & 278 & & \\
\hline \multirow{4}{*}{ Sosyal Arkadaşlık } & 0-9 Yil & 81 & 2,23 & ,766 & 2 & \multirow{4}{*}{, 515} & \multirow{4}{*}{,598 } \\
\hline & 10-14 Y1l & 93 & 2,33 & 820 & 276 & & \\
\hline & $20 Y_{11}+$ & 105 & 2,23 & ,707 & & & \\
\hline & Toplam & 279 & 2,26 &, 762 & 278 & & \\
\hline \multirow{4}{*}{$\begin{array}{l}\text { İş Yaşamında } \\
\text { Yalnızlık }\end{array}$} & $0-9$ Yil & 81 & 2,27 & ,737 & 2 & \multirow{4}{*}{,688 } & \multirow{4}{*}{, 503} \\
\hline & 10-14 Yil & 93 & 2,36 & ,728 & 276 & & \\
\hline & $20 \mathrm{Y}_{11}+$ & 105 & 2,25 & 640 & & & \\
\hline & Toplam & 279 & 2,29 & 698 & 278 & & \\
\hline
\end{tabular}

Tablo 11'e göre katılımcıların duygusal yoksunluk alt boyutu $\left(\mathrm{F}_{(2,276)}=, 634 ; \mathrm{p}>.05\right)$ ve sosyal arkadaşlık alt boyutu $\left(\mathrm{F}_{(2,276)}=, 515 ; \mathrm{p}>.05\right)$ puanları, katılımcıların kıdem yıllarına göre anlamlı düzeyde farklılaşmamaktadır. IYYÖ’nün tümünden alınan puanlar da kıdem y1llarına göre anlamlı düzeyde farklılaşmamaktadır $\left(\mathrm{F}_{(2,276)}=, 688 ; \mathrm{p}>.05\right)$.

Katılımcıların çalışma yaşamında yalnızlık puanlarının unvanlarına göre t-testi sonuçları Tablo 12'de yer almaktadir.

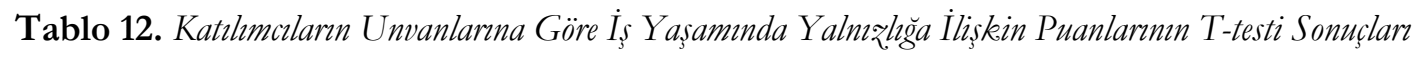

\begin{tabular}{|c|c|c|c|c|c|c|}
\hline Puanlat & Değişken & $n$ & $A O$ & $S$ & $t$ & $p$ \\
\hline \multirow{2}{*}{ Duygusal Yoksunluk } & Amir & 55 & 2,12 & ,607 & \multirow{2}{*}{$-2,094$} & \multirow{2}{*}{,037 } \\
\hline & Memur & 224 & 2,36 & ,799 & & \\
\hline \multirow{2}{*}{ Sosyal Arkadaşlık } & Amir & 55 & 2,08 & ,633 & \multirow{2}{*}{$-1,953$} & \multirow{2}{*}{, 052} \\
\hline & Memur & 224 & 2,31 &, 785 & & \\
\hline \multirow{2}{*}{ İş Yaşamında Yalnızlık } & Amir & 55 & 2,10 &, 573 & \multirow{2}{*}{$-2,234$} & \multirow{2}{*}{,026 } \\
\hline & Memur & 224 & 2,34 & ,719 & & \\
\hline
\end{tabular}

Tablo 12'ye göre katılımcıların duygusal yoksunluk alt boyutu puanları, kadro unvanlarına göre anlamlı düzeyde farklılaşmaktadır $\left(\mathrm{t}_{(279)}=-2,094 ; \mathrm{p}<.05\right)$. Buna göre, amir düzeyindeki katılımc1lar $(\mathrm{AO}=2,12)$, memur düzeydeki katılımcılara göre $(\mathrm{AO}=2,36)$ daha az duygusal yalnızlık yaşamaktadırlar. Sosyal arkadaşlık boyutunda katılımcıların görüşleri, kadro unvanlarına göre anlamlı düzeyde 
farklılaşmamaktadır $\left(\mathrm{t}_{(279)}=-1,953 ; \mathrm{p}>.05\right)$. Bununla birlikte, IYYÖ’nün geneli için amir pozisyonundaki katılımcıların puanları $(\mathrm{AO}=2,10)$, memur pozisyonundaki çalışanlara göre $(\mathrm{AO}=2,34)$ anlamlı düzeyde farklılaşmaktadır $\left(\mathrm{t}_{(279)}=-2,234 ; \mathrm{p}<.05\right)$. Bu durumda amir düzeyindeki katılımcıların, memur çalışma arkadaşlarına göre, yalnızlık düzeylerinin azaldı̆̆ı söylenebilir.

Katılımcıların çalışma yaşamında yalnızlık düzeylerine ilişkin puanlarının medeni durumlarına göre ttesti sonuçları Tablo 13'te yer almaktadır.

Tablo 13. Katılımalarn Medeni Durumlarına Göre Iss Yaşamında Yalnızlık Puanlarna İlişkin T-testi Sonuçlar

\begin{tabular}{|c|c|c|c|c|c|c|}
\hline Puanlar & Değişken & $n$ & $A O$ & $S$ & $t$ & $p$ \\
\hline Duygusal & Evli & 207 & 2,23 &, 719 & \multirow{2}{*}{$-3,057$} & \multirow{2}{*}{,054 } \\
\hline Yoksunluk & Bekâr & 71 & 2,55 & 869 & & \\
\hline Sosyal & Evli & 207 & 2,19 & ,692 & \multirow{2}{*}{$-2,882$} & \multirow{2}{*}{,012 } \\
\hline Arkadaşlık & Bekâr & 71 & 2,49 & ,910 & & \\
\hline İş Yaşamında & Evli & 207 & 2,21 & ,628 & \multirow{2}{*}{$-3,282$} & \multirow{2}{*}{,009 } \\
\hline Yalnızlik & Bekâr & 71 & 2,52 & ,837 & & \\
\hline
\end{tabular}

Tablo 13'e göre, katılımcıların duygusal yoksunluk boyutu puanları medeni durumlarına göre anlamlı düzeyde farklılaşmamaktadır $\left(\mathrm{t}_{(278)}=-3,057 ; \mathrm{p}>.05\right)$. Ancak katılımcıların sosyal arkadaşlık boyutu puanları, medeni durumlarına göre anlamlı düzeyde farklılaşmaktadır $\left(\mathrm{t}_{(278)}=-2,882 ; \mathrm{p}<.05\right)$. Buna göre evli katılımcılar $(\mathrm{AO}=2,19)$, bekâr katılımcılara $(\mathrm{AO}=2,49)$ göre sosyal arkadaşlık konusunda daha az yalnızlık yaşamaktadırlar. IYYYÖ'nün geneli için de katılımcıların puanları medeni durumlarına göre anlamlı düzeyde farklılaşmaktadır $\left(\mathrm{t}_{(278)}=-3,282 ; \mathrm{p}<.05\right)$. Ortalamalar dikkate alındığında evli katılımcıların puanlarının $(\mathrm{AO}=2,21)$, bekâr katılımcıların puanlarına göre $(\mathrm{AO}=2,52)$ daha düşük düzeyde olduğu görülmektedir. Başka bir deyişle evli katılımcılar, bekârlara göre çalışma yaşamında daha az yalnızlık yaşamaktadırlar.

\section{Katılımcıların iş doyumları ile çalışma yaşamında yalnızlık düzeyleri arasındaki ilişki}

Katılımcıların çalışma yaşamında yalnızlık puanları ile iş doyumu puanları arasındaki korelasyon analizi sonuçları, Tablo 14'te yer almaktadır.

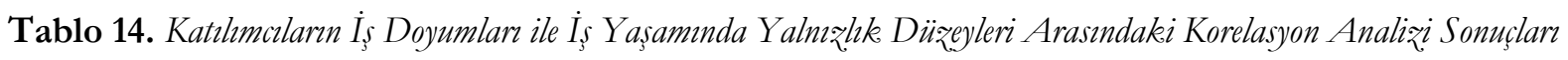

\begin{tabular}{|c|c|c|c|c|c|c|}
\hline & 1 & 2 & 3 & 4 & 5 & 6 \\
\hline 1. İçsel Doyum & 1 & & & & & \\
\hline 2. Dişsal Doyum &, $793^{* *}$ & 1 & & & & \\
\hline 3. İş Doyumu &, $951^{* *}$ &, $942^{* *}$ & 1 & & & \\
\hline 4. Duygusal Yoksunluk &,$- 486^{* *}$ &,$- 488^{* *}$ &,$- 514^{* *}$ & 1 & & \\
\hline 5. Sosyal Arkadaşlık &,$- 472^{* *}$ &,$- 442^{* *}$ &,$- 483^{* *}$ &, $655^{* *}$ & 1 & \\
\hline 6. Çalışma Yaşamında Yalnızlık &,$- 527^{* *}$ &,$- 513^{* *}$ &,$- 550^{* *}$ &, $933^{* *}$ &, $883^{* *}$ & 1 \\
\hline
\end{tabular}

Tablo 14'e göre katılımcıların iş doyumu ile çalışma yaşamında yalnızlık puanları arasında negatif yönlü bir ilişki bulunmaktadır $(\mathrm{r}=-0,550)$. Bu durum, çalışma yaşamında yalnızlık düzeyi arttıkça, iş doyumunun azalacağı anlamına gelmektedir. Bununla birlikte, MİDÖ’nün içsel doyum boyutu ile IYYÖ'nün duygusal yoksunluk $(r=-0,486)$, sosyal arkadaşlık boyutu $(r=-0,472)$ ve ölçeğin geneli $(r=-0,527)$ puanları arasında da negatif bir ilişki bulunmaktadır. Benzer şekilde MíDÖ'nün dişsal doyum boyutu ile IYYÖ'nün duygusal yoksunluk $(r=-0,488)$, sosyal arkadaşlik boyutu $(r=-0,442)$ ve ölçeğin geneli $(r=-0,513)$ puanlar arasında da negatif yönlü bir ilişki bulunmuştur. Ayrıca MİDÖ’nün geneli ile IYYÖ’nün duygusal yoksunluk $(r=-0,514)$ ve sosyal arkadaşlık boyutu $(r=-0,483)$ puanları arasında da negatif yönlü bir ilişki bulunmaktadir.

\section{Katılımcıların iş yaşamında yalnızlık ile cinsiyet, kıdem, unvan, yaş, medeni durum ve kadro birimleri değişkenlerinin iş doyumunu yordama düzeyleri}

Tablo 15’te katılımcıların çalışma yaşamında yalnızlık ile cinsiyet, kıdem, unvan ve medeni durum değişkenlerinin iş doyumunu yordama düzeylerine ilişkin basit doğrusal regresyon analiz sonuçları yer almaktadir. 
Katılımcıların, IYYÖ’nün alt boyutları ile diğer değişkenlerle birlikte MİDÖ’nün geneli puanlarının anlamlı bir yordayıcısıdır, $\left(\mathrm{R}=0,587, \mathrm{R}^{2}=0,344, \mathrm{~F}_{(9,268)}=15,630, \mathrm{p}<.01\right) . \mathrm{Bu}$ sonuç, iş doyumuna ilişkin varyansin \% 34,4'ünün IYYÖ ve alt boyutları ile katılımciların cinsiyet, kıdem, unvan ve medeni durum değişkenleri tarafından açıklandığını göstermektedir.

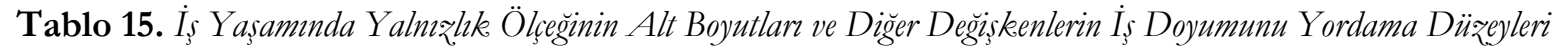

\begin{tabular}{|c|c|c|c|c|c|c|c|c|c|c|c|c|c|c|c|}
\hline & \multicolumn{5}{|c|}{ Ícsel Doyum } & \multicolumn{5}{|c|}{ Dissal Doyum } & \multicolumn{5}{|c|}{$\dot{I}_{S}$ Doyumu } \\
\hline & $B$ & $S H$ & $\beta$ & $t$ & $p$ & $B$ & $S H$ & $\beta$ & $t$ & $p$ & $B$ & $S H$ & $\beta$ & $t$ & $p$ \\
\hline Sabit & 4,833 &, 380 & - & 12,726 & 000 & 4,785 & 438 & - & 10,928 & 000 & 4,811 &, 375 & - & 12,826 &, 000 \\
\hline Duyg. Yoks. [DY] &,- 283 & 063 &,- 299 & $-4,466$ & 000 &,- 370 & 073 &,- 346 & $-5,060$ & 000 &,- 322 & 063 &,- 340 & $-5,144$ & 000 \\
\hline Sosyal Ark. [SA] &,- 257 & 064 &,- 269 & $-4,015$ & 000 &,- 233 & 074 &,- 215 & $-3,153$ & 002 &,- 246 & 063 &,- 257 & $-3,891$ & 000 \\
\hline Cinsiyet [C] & 081 & 076 &, 056 & 1,063 & 289 & ,181 & 088 & 109 & 2,055 & 041 & ,126 & 075 & 086 & 1,671 & 096 \\
\hline Kidem $[\mathrm{K}]$ & ,115 & 066 & ,129 & 1,738 & 083 & 091 & 077 & ,089 & 1,182 & 238 & ,104 & 066 & 116 & 1,589 & 113 \\
\hline Yaş [Y] & 031 & 061 & 037 &, 512 & 609 &,- 012 & 070 &,- 013 &,- 173 & 863 & ,012 & 060 & ,014 & ,194 & 846 \\
\hline Med. Drm. [MD] &,- 056 & 089 &,- 033 &,- 626 &, 532 &,- 003 & ,103 &,- 001 &,- 026 & 979 &,- 032 & 088 &,- 019 &,- 362 & ,718 \\
\hline Unvan [U] &,- 110 & ,105 &,- 060 & $-1,048$ & 296 &,- 169 & ,121 &,- 082 & $-1,393$ & ,165 &,- 136 & 104 &,- 074 & $-1,315$ & 190 \\
\hline Kadro Birimi $[\mathrm{KB}]$ &,- 063 & ,075 &,- 043 &,- 835 & ,404 &,- 059 & 087 &,- 035 &,- 677 & ,499 &,- 061 & ,074 &,- 041 &,- 820 & ,413 \\
\hline \multicolumn{6}{|c|}{$\mathrm{R}=, 569 \mathrm{R}^{2}=, 324$} & \multicolumn{5}{|c|}{$\mathrm{R}=, 546 \mathrm{R}^{2}=, 298$} & \multicolumn{5}{|c|}{$\mathrm{R}=, 587 \mathrm{R}^{2}=, 344$} \\
\hline
\end{tabular}

Regresyon analizi sonucuna göre iş doyumunu yordayan regresyon denklemi, şu şekilde kurulabilir.

İş $\quad$ Doyumu $=4,811+(-0,32) \mathrm{DY}+(-0,25) \mathrm{SA}+0,13 \mathrm{C}+0,01 \mathrm{Y}+0,10 \mathrm{~K}+(-0,06) \mathrm{ED}+(-0,03) \mathrm{MH}+(-0,14)$ $\mathrm{U}+(-0,06) \mathrm{KB}$

\section{Tartışma, Sonuç ve Öneriler}

Araştırmaya katılan idari çalışanların iş doyumları, "orta ve üzeri” memnuniyet düzeyine karşıllk gelmektedir. Katılımcıların yüksek düzeyde katıldıkları maddeler, çalışma yaşamının genel niteliğiyle ilgilidir. İdari çalışanların sürekli bir işe sahip olmayı önemsedikleri anlaşılmaktadır. Bu bakımdan kadro güvencesinin çalışanların doyum düzeylerini etkileyen özelliklerin başında geldiği söylenebilir. Başkaları için bir şeyler yapmaktan memnun olmaları, eğitim gibi hizmet sektöründeki işlerin en önemli niteliklerinden birisi olması bakımdan önemli görülebilir. Eğitim hizmetinin yerine getirilmesinde önemli bir sorumluluk üstlenen idari çalışanların, üniversitenin diğer bileşenleri ile yardımlaşma, etkileşme ve onları önemseyerek bir şeyler yapmaktan doyum elde etmeleri önemli bir bulgu olarak görülebilir.

Diğer yandan idari çalışanların daha düşük düzeyde memnuniyet belirttikleri maddelere bakıldığında, yaptıkları işin ilerleme olanakları, ücret düzeyi ve karar verme sürecine ilişkin puanlarının, diğer maddelere göre düşük düzeyde olmasının, doyum düzeylerini düşüren öncelikli konular olduğu anlaşılmaktadır. İlerleme olanakları hem toplumsal statü hem de özlük hakları açısından önemlidir.

$\mathrm{Bu}$ araştırmanın sonuçları daha önce yapılmış araştırma sonuçlarıyla birlikte ele alındığında, idari çalışanların, daha nesnel kariyer ilerlemesi koşulları ve yaşamını sürdüreceği ücret düzeyinin yükselmesi ile birlikte daha fazla inisiyatif alarak çalışabilme imkanına kavuşması durumunda, iş doyumu düzeylerinin yükseleceği ileri sürülebilir. Yine bu araştırmada iş doyumu puanlarının cinsiyete göre farklılaşmaması, işdoyumu konusunda çok sayıda araştırmanın bulgularıyla örtüşmektedir (Chung, Jung ve Sohn, 2017; Çakmak, 2016; Gündüz, 2016; Sarıboğa, 2017; Şangar, 2016; Ünverdi, 2016).

$\mathrm{Bu}$ çalışmada içsel doyum ve genel iş doyumu için meslek yaşamının sonlarına yaklaşmakta olan katılımcıların doyum düzeylerinin, genç çalışma arkadaşlarına göre daha yüksek olduğu sonucuna ulaşılmıştır. Bu sonuç, çalışma süreleri arttıkça katılımcıların yaptıkları işi daha fazla içselleştirdikleri, sürekli bir işe sahip olmaktan duydukları memnuniyetin yanında, başkaları için bir şeyler yapabilme ve sürekli bir şeylerle meşgul olma olanaklarından duydukları memnuniyetin, zaman içerisinde kümeli bir etki yaratarak iş doyumu düzeylerini de arttırdığ şeklinde yorumlanabilir. Bununla birlikte genel olarak ilgili alanyazında iş doyumu ile kıdem arasındaki ilişkinin yönü ve boyutu konusunda bir tutarlılık bulunmadığı söylenebilir.

Alanyazında, birçok araştırmada (Baykoca, 2012; Çakmak, 2016; Dedebali, 2010; Gündüz Orhaner, 2016; Mertoğlu, 2013; Öz, 2006; Subulan, 2015), çalışanların hizmet sürelerinin iş doyumunu etkilediği belirlenmiştir. Gündüz Orhaner'in (2016), banka çalışanları üzerinde yaptığı araştırmada, meslek hayatının henüz başlangıcında olan beş yıldan az kıdeme sahip çalışanlar ile en yüksek seviyede,16-20 yıl, kıdeme sahip olan çalışanların iş doyumu düzeylerinin, diğer çalışma arkadaşlarına göre daha fazla olduğunu belirlemişlerdir. Çakmak’a (2016) göre de kıdem ile iş doyumu arasında anlamlı bir ilişki bulunmaktadır. 
Subulan'ın (2015) çalışmasında da kıdem değişkenine göre iş doyumu düzeyinin anlamlı bir biçimde farklılaştı̆̆ belirlenmiştir. Benzer şekilde Baykoca (2012) da, iş doyumu ile kıdem arasında anlamlı bir ilişskinin varllğına işaret etmekte ve iş doyumu düzeyinde dengenin, çalışma süresi daha uzun olan gruplar lehine bozulduğunu belirtmektedir. Dedebali’nin (2010) emniyet teşkilatı çalışanları üzerinde gerçekleştirdiği çalışmanın sonucuna göre, kıdemi 21 yıl ve daha fazla olan polislerin iş doyumu düzeyleri diğerlerine göre yüksektir. Öz (2006) tarafindan turizm sektörü yöneticileri arasında yapılan başka araştırmada ise bir yıldan az süre çalışanların, 1-3 yıl arası kıdeme sahip olanlara göre; 5-7 y1l arası kıdemi olanların 1-3 yıl kıdemi olanlara göre ve 7-9 yıl kıdemi olanların da 3-5 yıl kıdemi olan yönetici meslektaşlarına göre iş doyumları istatistiki olarak daha yüksek bulunmuştur. Alanyazındaki araştırma sonuçlarının farklılık göstermesi, çalışma grubunun sosyal ve kültürel nitelikleri ile bağlantılı olabileceği gibi inceleme konusu yapılan meslek grubunun kendine has nitelikleri ve hatta yine araştırmanın yapıldığı zaman ile de ilgili olabilir.

Katılımcıların iş doyumu, görev unvanlarına göre farkllık göstermektedir. Şef ve üzeri kadro unvanlarındaki katılımcıların iş doyumları, memur katılımcıların iş doyumlarından anlamlı düzeyde yüksektir. Kadro unvanının yükselmesine bağlı olarak yetki, sosyal statü, özlük hakları gibi konularda iyileşme olması, görüş farklılığının oluşmasına etkide bulunmuş olabilir. İlgili alanyazında, çalışanların unvanları ile iş doyumu düzeyleri arasındaki ilişkiyi inceleyen araştırmaların (Baykoca, 2012; Çakmak, 2016; Çoban, 2017; Elyas, 2016; Emre, 2016; Ghafoor, 2012; Karagöz, 2016; Ölçüm, 2015) sonuçlar1 çeşitlilik göstermektedir. Çalş̧anların unvanları ile iş doyumları arasında istatistiki olarak anlamlı bir ilişski tespit edilemeyen çalışmalar olduğu gibi (Baykoca, 2012; Kilıç vd., 2013) çalışlan pozisyonun iş doyumu üzerinde etkisi olduğunu savunan araştırmalara da fazladır. Çoban'ın (2017) kamu ve özel sektör çalışanları ile gerçekleştirdiği çalışmasında, özel sektörde işveren statüsünde olan bireylerin iş doyumlarının, yönetici ve işçi statüsünde olan bireylere göre anlamlı biçimde daha yüksek olduğu belirlenmişken, kamu sektöründe ise istatistiki olarak anlamlı düzeyde bir farklılığa ulaşılamamıştır. Ghafoor’un (2012) üniversitelerde gerçekleştirdiği araştırmasında da profesörlerin iş doyumu, diğer tüm çalışanların iş doyum düzeylerinden daha yüksek bulunmuştur. Diğer yandan Karagöz'ün (2016) ve Çakmak'nn (2016) çalışmalarında, idari yapılanmada alt konumlardaki çalışanların iş doyumu, daha iyi koşullardaki çalışanlara göre daha yüksek çımıştır. Unvan ile iş doyumu düzeyi arasındaki ilişkide beklenti, yetki ve sorumluluklar arttıkça iş doyumunun da artacağ yönünde olsa dahi, uygulamada durumun farklılaşabileceği anlaşılmaktadır. Ancak bu araştırmada Mersin Üniversitesi idari çalısanlarının, yönetsel hiyerarşide üst seviyelere çıkmalarının, iş doyumu düzeylerini arttırdığı belirlenmiştir.

Katılımcıların iş doyumu düzeyleri medeni durum değişkenine göre anlamlı düzeyde farklılaşmaktadır. Evli katılımcıların iş doyumu düzeyleri, bekâr katıllımcıların iş doyumu düzeylerinden yüksektir. Bu durum, katılımcıların aile yaşantılarının, iş doyumu üzerinde bir etkiye sahip olduğu biçiminde yorumlanabilir. Ayrıca evli çalışanların artan sorumluluk yüklerini, çalışma yaşamı sorumlulukları ile bir potada eriterek birlikte değerlendirdikleri ve bu durumu kendileri lehine bir üstünlük haline getirebildikleri yani evlilikle birlikte düzenli bir hayata geçilmiş olmasının çalışma yaşamı üzerinde de olumlu etkilere sahip olduğu söylenebilir.

Çalışanların medeni durumlan ile iş doyumu düzeyleri arasındaki ilişkinin konu edinildiği çalışma sonuçları arasında tutarlılık bulunmamaktadır. Bununla birlikte alanyazında evli çalışanların bekâr çalışanlara göre iş doyumlarının daha yüksek olduğu buna sebep olarak ise bireylerin evlendikten sonra artan sorumluluklarının yaptıkları işten daha fazla doyum elde etmelerinde etkili olduğu belirtilmektedir (Çoban, 2017). Benzer şekilde Şangar’a (2016) göre, bekâr çalışanların iş doyumu düzeyleri evlendiklerinde olumlu biçimde farklılık göstermektedir. Emre’ye (2016) göre de evli çalışanların, bekâr ve boşanmış durumda olan meslektaşlarına nazaran iş doyumları daha yüksek düzeydedir.

Araştırmada katılımcıların iş yaşamında yalnızlık çekme konusunda ciddi sorunlar yaşamadıkları anlaşılmışır. Katılımcılar büyük ölçüde maddelere katılmamak ile kararsız kalmak arasında bir düzeyde görüş belirtmişlerdir. İş yaşamında yalnızlık puanlarının görece düşük olması, idari çalışanların iş yaşamında yalnızlık konusunda yaygın bir sorunlarının olmadığını göstermektedir. Bazı maddelerde ortalamaların yükselmesi, belirli durumların veya duyguların sınırlı olarak yaşanabildiği biçiminde yorumlanabilir. İşs yerinde dostluk anlayışının varlığı konusunda kararsız kalan idari çalışanlar, iş arkadaşlanı tarafından dışlanmadığını düşünmektedirler. Ayrıca baskı altında kaldığında destek gördüklerini düşünürlerken, diğer yandan çalışma arkadaşlarıyla bir kopukluk hissetmemektedirler. 
Katılımcıların iş yaşamında yalnızlık puanları cinsiyete göre anlamlı bir farklılı̆̆ın olmadığını göstermiştir. Başka bir ifadeyle idari çalışanların cinsiyeti, yalnızlık duygusu yaşamalarında etkili değildir. Konu ile ilgili alanyazında benzer sonuçlara ulaşıldığ gözlemlenmiştir. IYYÖ'yü geliştiren Wright (2005; 2006) iki çalışmasında, cinsiyet ile çalışma yaşamında yalnızlık arasında anlamlı bir ilişki olmadığı sonucuna ulaşmıştır. Yine Keser ve Karaduman'a (2014) göre cinsiyet değişkeni ile çalışma yaşamında yalnızlık arasında anlamlı bir ilişki bulunmamaktadır. Benzer bir sonuca Mercan ve diğerlerinin (2012) çalışmasında da ulaşılmıştır. Aslan Yılmaz ve Dönmez (2013) tarafindan gerçekleştirilen çalışmada da çalışma yaşamında yalnızlık ile cinsiyet arasında bir ilişki belirlenememiştir.

Araştırmada katılımcıların, çalışma yaşamında yalnızlık puanlarının meslekte geçirdikleri süre değişkenine göre anlamlı düzeyde farklılık göstermemiştir. Karakurt (2012) da çalışılan sürenin çalışma yaşamında yalnızlık üzerinde istatistiksel olarak herhangi bir etkisi bulunmadığını savunmaktadır. Bunun yanında, çalışma hayatında geçirilen süre değişkeni ile çalışma yaşamında yalnızlık arasında anlamlı ilişki olduğunu savunan araştırmalara da rastlanmaktadır. Keser ve Karaduman'ın (2014) çalışmasında yirmi yıldan fazla kıdeme sahip öğretmenlerin, beş-on yıl kıdeme sahip öğretmenlere göre daha fazla çalışma yaşamı yalnızlı̆̆ı yaşadıkları belirlenmiştir. Mercan ve diğerleri (2012) tarafından yapılan çalışmada ise duygusal yoksunluk alt boyutu ile çalışma süresi arasında düşük düzeyde pozitif yönlü anlamlı bir ilişki belirlenmiştir. Kaplan'ın (2011) çalışmasında da kıdem değişkeni ile çalışma yaşamında yalnızlık düzeyi arasında anlamlı bir farkın olduğu belirlenmiştir.

Katılımcıların, IYYÖ puanlarının kadro unvanı değişkenine göre anlamlı düzeyde farklılaştı̆̆ belirlenmiştir. Buna göre üst görev unvanında yer almayan idari çalışanlar, amirlerine göre daha fazla çalısma yaşamı yalnızlı̆̆ yaşamaktadırlar. Bununla birlikte Wright (2005) da istihdam şekilleri (employment status) ile çalışma yaşamında yalnızlık arasında önemli bir ilişki bulunmadığını ifade etmiştir. Benzer olarak Demirbaş’ın (2014), çalışanların unvanları ile çalışma yaşamı yalnızlığı arasındaki ilişkiye yönelik yaptı̆̆1 çalısmada da anlamlı bir farka rastlanmamıştır.

Katılımcıların çalışma yaşamında yalnızlık puanlanı, medeni durum değişkenine göre anlamlı düzeyde farklılaşmaktadır. Buna göre, bekâr çalışanların, evli çalışanlara göre, ölçeğin geneli ve sosyal arkadaşılk alt boyutu puanları yüksektir. Bir başka ifadeyle bekâr çalışanlar, evli çalışanlara göre çalışma yaşamında daha fazla yalnızlık yaşamaktadırlar. Çalışma yaşamında yalnızlık konusunda, bekâr çalışanların evli çalışanlara kıyasla dezavantajlı olmaları, beklenen bir sonuç olarak görülebilir. Ayrıca çalışanların medeni durumlarına göre dağılımları da bunda etkide bulunmuş olabilir. Araştırmaya katılan evli çalışanların (207 çalışan), bekâr çalışanlara (70) göre sayıca fazla olması, bekâr çalışanların sosyalleşmelerinde sınırlayıcı bir etken haline gelmiş olabilir. Şöyle ki, medeni duruma göre çalışanların yaşamlarındaki öncelikli konuların farklılaşması nedeniyle, bekâr çalışanların sayıca az olmalarına bağlı olarak, benzer durumdaki çalışanlarla etkileşme olanaklanı, sayıca fazla olan evli çalışanlara göre daha sınırlı düzeyde olabilir. İlgili alanyazında bu araştırma bulgularını destekleyen çalışmalar bulunduğu gibi, farklı sonuçlara ulaşan çalışmalar da bulunmaktadır. Demirbaş ve Haşit (2016), çalışanların medeni durumları ile çalışma yaşamında deneyimledikleri yalnızlık düzeyi arasında kısmen anlamlı bir ilişki olduğunu ve hiç evlenmemiş olanların çalışma yaşamında evlilere göre kendilerini daha az yalnız hissettikleri, evlenip boşananların da hiç evlenmemiş olanlara göre çalışma yaşamında kendilerini daha az yalnız hissettiklerini belirlemişlerdir. Bakioğlu ve Korumaz'n (2014) yaptıkları çalşsmada da yine medeni durum ile çalışma yaşamı yalnızlığı arasında anlamlı bir ilişski belirlenmiştir. Çalışmada bekâr çalışanların, evli çalışanlara göre daha fazla çalışma yaşamı yalnızlı̆̆ yaşadığı ileri sürülmüştür. Yılmaz ve Aslan (2013) ise iş yaşamında yalnızlı̆̆ın sosyal arkadaşlık alt boyutunda anlamlı bir fark belirlemişlerdir. Çalışmada bekâr çalışanların, evli çalışanlara göre daha fazla çalışma yaşamında yalnızlık yaşadığı belirlenmiştir. Karakurt'a (2012) göre de medeni durum ile çalışma yaşamında yalnızlık arasında, bekârların aleyhine anlamlı bir ilişki bulunmaktadır.

Katılımcıların iş doyumu ile çalışma yaşamında yalnızlıkları arasında negatif yönlü bir ilişki bulunmaktadır. Diğer bir deyişle idari çalışanların çalışma yaşamında yalnızlık düzeyi arttıkça, iş doyumları azalmaktadır. Üniversite idari çalışanlarının iş yeri yalnızlı̆ının, iş ve yaşam doyumu üzerindeki etkisini lider üye etkileşimin aracılık rolü bağlamında ele alan Cindiloğlu, Polatcı, Özçalık ve Gültekin (2017), çalışma yaşamı yalnızlığ ile iş doyumu arasında negatif yönlü bir ilişki olduğunu belirlemişlerdir. Yine Wright'ın (2005) araştırmasında da çalışma yaşamında yalnızlık ile iş doyumu arasında negatif yönlü bir ilişki belirlenmiştir. Tüm bu sonuçlar, iş yerinde yalnızlığı artan çalışanın iş doyumunun da düşeceğini göstermektedir. 
Katılımcıların iş doyumu ölçeğine verdikleri yanıtlardan; çalışma yaşamında yalnızlık ölçeği ile cinsiyet, kıdem, unvan, yaş ve medeni durum değişkenleri tarafindan, içsel doyuma ilişkin varyansın \% 32,4'ü; dişsal doyuma ilişkin varyansın \% 29,8’i ve iş doyumuna ilişkin toplam varyansın \% 34,4'ünün açılamaktır. Başka bir ifadeyle çalışma yaşamında yalnızlık duygusu, iş doyumunun anlamlı yordayıcısıdır. Bu bakımdan çalş̧anların iş doyumunun konu edinildiği durumlarda, çalışanlar arasındaki sosyal ilişkilerin dikkate alınması önemlidir.

\section{Sonuç}

Araştırmanın sonuçları şöyle sıralanabilir:

- Katılımcıların iş doyumu düzeyleri orta ve üzeridir. Kattlımcılar, başkaları için bir şeyler yapma ve vicdanına ters düşmeyen işler yapmayı iş doyumu açısından diğer etkenlerden daha önemli görmektedirler.

- Kadın ve erkek katılımcıların iş doyumu düzeyleri birbirine yakındır.

- Katılımcıların iş doyumu konusundaki görüşleri, kıdemlerine göre anlamlı düzeyde farklılaşmaktadır. Kıdem arttıkça iş doyum düzeyinde de anlamlı bir farklılaşma olmaktadır.

- Katılımcıların iş doyumu konusundaki görüşleri kadro durumlarına göre anlamlı düzeyde farklılaşmaktadır. Amir pozisyonundaki katılımcıların iş doyum düzeyleri, memur pozisyonundaki katılımcilardan yüksektir.

- Katılımcıların iş doyumu, medeni durumlarına göre anlamlı düzeyde farklılaşmaktadır. Evli katılımcıların iş doyumu, bekâr katılımcılara göre daha yüksek düzeydedir.

- Katılımcılar, çalışma yaşamlarında belirgin bir yalnızlık yaşamamaktadırlar.

- Katılımcıların çalışma yaşamındaki yalnızlık duygusu cinsiyete göre anlamlı düzeyde farklılaşmamaktadır.

- Katılımcıların, çalışma yaşamındaki yalnızlık duygusu kıdeme göre anlamlı düzeyde farklılaşmamaktadır.

- Katılımcıların çalışma yaşamındaki yalnızlık duygusu, çalışılan pozisyona göre anlamlı biçimde farklılaşmaktadır. Buna göre şef ve üzeri kadrolardaki katılımcılar, daha alt düzeydeki katılımcılara göre daha az duygusal yalnızlık yaşamaktadırlar. Başka bir deyişle memur kadrosundaki katılımcılar, daha üst kadrolardaki katıllımcılardan sayıca fazla olmalarına karşın, daha çok duygusal yalnızlık yaşamaktadırlar.

- Katılımcıların IYYÖ geneli ve sosyal arkadaşlık alt boyutu konusundaki görüşleri, medeni duruma göre göre anlamlı düzeyde farklılaşmaktadır. Buna göre evli çalışanlar, bekârlara göre iş yaşamında yalnızlık ve sosyal arkadaşlık konusunda daha az yalnızlık yaşamaktadırlar.

- Katılımcıların iş doyumu ile çalışma yaşamında yalnızlık düzeyleri arasında negatif yönlü bir ilişki bulunmaktadır. Buna göre, çalışanların çalışma yaşamında yalnızlık düzeyleri arttıkça, iş doyumları azalmaktadir.

\section{Öneriler}

Araştırma sonuçlarına dayalı öneriler, şöyle sıralanabilir:

- Elde edilen sonuçlara göre iş doyumu düzeyini düşüren önemli öğeler, kariyer olanakları ve kendi kararını verme özgürlüğ̈ konusundaki kısıtlılıklardır. Bu bağlamda yönetici iradenin görevde yükselme ve atamalarda liyakati göz önünde bulundurarak kararlar almasının ve yönetim kademesinin en alt düzeyinden başlamak üzere, astlara idari iş ve işlemlerde daha geniş hareket alanlarının sağlanması yönünde düzenleme ve uygulamalara gidilmesinin, iş doyumuna olumlu etkileri olacaktır.

- Ücret düzeyi ile ilgili olarak algilanan yetersizlik de iş doyumunu olumsuz etkilemekte olup, çözüm boyutunda daha makro düzeyde bir takım ekonomi-politik değişimleri gerektirmektedir. Bununla birlikte, bütçe koşulları elverdiği ölçüde ilgili mevzuatta öngörülen, döner sermaye ve 
ikinci öğretim gelirleri gibi parasal olanakların idari çalışanlar için de kullanılmasının olumlu yansimaları olacaktır.

- Araştırmanın bir diğer boyutu olan çalışma yaşamında yalnızlık olgusuna ilişkin olarak çalışma ortamında arkadaşlığı pekiştirici, hiç kimsenin kendisini dışlanmış hissetmeyeceği biçimde kapsayıcı nitelikte, çalışanların bir arada ve nitelikli zaman geçirmesini sağlayacak sosyal ve kültürel ortamlar sağlanması önemlidir.

- İş yaşamında yalnızlı̆ga neden olarak düşünülebilecek günlük yaşam gerilimini en aza indirmek adına idari çalışanlara yönelik olarak, stresle başa çıkma ve öfke yönetimi gibi konularda hizmet içi eğitim etkinlikleri düzenlenebilir.

- Çalışma yaşamında yalnızlık ve iş doyumu ilişkisinin, akademik çalışanlar bağlamında ele alınması da önemli sonuçlar sunacaktır.

\section{Etik Beyan}

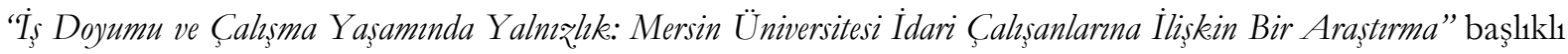
çalısmanın yazım sürecinde bilimsel, etik ve alıntı kurallarına uyulmuş; toplanan veriler üzerinde herhangi bir tahrifat yapılmamış, daha önce bir kaynakta veya bilimsel toplantıda yayımlanmamıştır. Araştırmada etik ilkelere uyulduğunu gösteren 08.03.2016 tarihli 2016/06 karar sayll "MEÜ Sosyal Bilimler Araştırmaları Etik Kurul" kararı alınmıştır.

\section{Kaynakça}

Al, D. A. (2016). Kısmi zamanl çalışanlarla tam zamanl çalı̧̧anlarn bireysel performans düzeylerinde is tatmininin rolü (Yüksek Lisans Tezi). Marmara Üniversitesi, İstanbul.

Aksu, N. (2012). İş tatmininin demografik değişkenler açısından incelenmesi. Polis Bilimleri Dergisi, 14(1), 59-80.

Aslan Yılmaz, D. ve Dönmez, A. (2013). İş doyumunu tayin eden bazı psikolojik ve demografik değişkenler. Türk Psikoloji Yazılar, 16(31), 91-97.

Bakioğlu, A. ve Korumaz, M. (2014). Öğretmenlerin okulda yalnızlıklarının kariyer evrelerine göre incelenmesi. Eğitim Bilimleri Dergisi, 39, 25-54.

Baycan, A. F. (1985). An analysis of the several aspects of job satisfaction between different occupational groups (Yüksek Lisans Tezi). Boğaziçi Üniversitesi, İstanbul.

Baykoca, Z. (2012). Üniversitelerde idari personelin iş doyumlarna ilişkin algzlar (Gaz̨i Üniversitesi ömeği) (Yüksek Lisans Tezi). Gazi Üniversitesi, Ankara.

Chung, E. K., Jung, Y. ve Sohn Y. W. (2017). A moderated mediation model of job stress, job satisfaction, and turnover intention for airport security screeners. Safety Science, 98, 89-97.

Cindiloğlu, M., Polatc1, C., Özçalık, F. ve Gültekin, Z. (2017). İş yeri yalnızlığının iş ve yaşam tatminine etkisi: Liderüye etkileşiminin aracılık rolü. Ege Akademik Bakıss, 17(2), 191-200.

Çakmak, B. (2016). Biçimsel örgütlerde iş tatmini ve örgütsel bağhllk üzerine bir araştırma: Aras kargo örneği (Yüksek Lisans Tezi). KTO Karatay Üniversitesi, Konya.

Çelik, V. (1987). Teknik ögretmenlerin is doyumsuzluğu ve ögretmenlikten aymlmalarna etkisi (Yüksek Lisans Tezi). Ankara Üniversitesi, Ankara.

Çetin, A. ve Alacalar, A. (2016). İş yaşamında yalnızlığ yordamada kişilik özellikleri ile algılanan sosyal ve örgütsel desteğin rolü. Uluslararası Yönetim İktisat ve İsletme Dergisi, 12(27), 193-216.

Çoban, F. (2017). Kamu ve öz̧el kurumlarda çalışan kişilerin mesleki doyum ve yaşam doyumlarmm karşılaştırlması (Yüksek Lisans Tezi). Nişantaşı Üniversitesi, İstanbul.

Dedebali, K. (2010). Hiẓmetiçi eğitimin emniyet teşkilatında görevli personelin iş doyumu ve performanslarna etkileri (İstanbul ili örneği) (Yüksek Lisans Tezi). Kırıkkale Üniversitesi, Kırıkkale.

Demir, A. (1990). Üniversite ögrencilerinin yalnız̨lk düzeylerini etkileyen bazı etmenler (Yüksek Lisans Tezi). Hacettepe Üniversitesi, Ankara.

Demirbaş, B. (2014). Iss yerinde yalnız̆h̆ğn ișten aymlma niyetine etkisinin belirlenmesine yönelik bir uygulama (Yüksek Lisans Tezi). Bilecik Şeyh Edebali Üniversitesi, Bilecik.

Demirbaş, B. ve Haşit, G. (2016). İş yerinde yalnızlık ve işten ayrılma niyetine etkisi: Akademisyenler üzerine bir uygulama. Anadolu Üniversitesi Sosyal Bilimler Dergisi, 16(1), 137-158.

Devlet Memurlar1 Kanunu, 657 (1967).

Doğan, T., Çetin, B. ve Sungur, M. Z. (2009). İş yaşamında yalnızlık ölçeği türkçe formunun geçerlilik ve güvenilirlik çalışmasi. Anadolu Psikizyatri Dergisi, 10(4), 271-277.

Duy, B. (2003). Bilişsel davramış̧ yaklaşıma dayalı grupla psikolojik damıșmanın yalmı̨llk ve fonksiyonel olmayan tutumlar üzerine etkisi (Doktora tezi). Ankara Üniversitesi, Ankara.

Emre, G. (2016). Ișs tatmini ve örgütsel bağhlik etkileşimi: İstanbul ili lojistik firmalar çalışanlar üzerine bir uygulama (Yüksek Lisans Tezi). İstanbul Gelişim Üniversitesi, İstanbul. 
Elyas, S. (2016). Calı̧san memnuniyetinin să̆lanmasında örgütsel etmenlerin rolü: Bir öẓel hastaneye ilişkin araștırma (Yüksek Lisans Tezi). İstanbul Üniversitesi, İstanbul.

Ernst, J. M. ve Cacioppo, J. T. (1999). Lonely hearts: Psychological perspectives on loneliness. Applied \& Preventive Psychology, 8, 1-22.

Gierveld, J. J., Tilburg, T. ve Dykstra, P. A. (2006). Loneliness and social 1solation. İçinde A. Vangelisti ve D. Perlman, (Edt.). Cambridge Handbook of Personal Relationships (ss. 485-500). Cambridge: Camridge University Press.

Ghafoor, M. M. (2012). Role of demographic characteristics on job satisfaction. Far East Journal of Psychology \& Business, 6(1), 30-45.

Gumpert, D. E. ve Boyd, D. P. (1984). The loneliness of the small-buiness owner. Harvard Business Review, NovemberDecember, 18-24.

Gündüz, B., Çapri, B. ve Gökçakan, Z. (2013). Mesleki tükenmişlik, ișle bütünleşme ve iş doyumu arasınndaki ilişkilerin incelenmesi. Eğitim Bilimleri Araștırmalar Dergisi, 3(1), 29-49.

Gündüz Orhaner, G. (2016). Banka çalşsanlarmın iş doyumu ve iş doyumunun örgütsel bağhluğa etkisi (Yüksek Lisans Tezi). Gazi Üniversitesi, Ankara.

Hellman, C. M. (1997). Job satiffaction and intent to leave. The Journal of Social Psychology, 137(6), 677-689.

İmamoğlu, S. (2008). Genc yetişkinlikle kişilerarası ilişkilerin cinsiyet, cinsiyet rolleri ve yalnıðlı algisı açısndan değerlendirilmesi (Doktora tezi). Marmara Üniversitesi, İstanbul.

Kaplan, M. S. (2011). Öğretmenlerin is yerinde yalmı̨̨lk duygularmın okullardaki örgütsel güven düreyi ve baz! deģ̆̈skenler açısından incelenmesi (Yüksek Lisans Tezi). Selçuk Üniversitesi, Konya.

Karaduman, M. (2013). Iss yaşaminda yalnız̨lk algısınn örgütsel vatandaşlık davranısı ile ilişkisi ve ögretmenler üzerinde bir uygulama (Yüksek Lisans Tezi). Uludağ Üniversitesi, Bursa.

Karagöz, Ö., S. (2016). T.C. Aile ve Sosyal Politikalar Bakanlğ̆ Konya ili çalışanlarmm is doyum düzeylerinin demografik özellikler açısindan incelenmesi (Yüksek Lisans Tezi). Ankara Üniversitesi, Ankara.

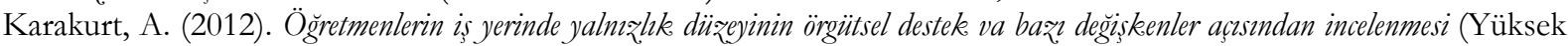
Lisans Tezi). Necmeddin Erbakan Üniversitesi, Konya.

Kaymaz, K., Eroğlu, U. ve Sayılar, Y. (2014). Effects of loneliness at work on the employees' intention to leave. İs, güc Endüstri İliskileri ve Insan kaynaklar Dergisi, 16(1), 38-53.

Keser A. ve Karaduman, M. (2014). İş yaşamında yalnızlık algısının örgütsel vatandaşlık davranışı ile ilişkisi ve öğretmenler üzerinde bir araştırma. HAK-İS Uluslararası Emek ve Toplum Dergisi, 3(7), 178-197.

Khalid, K., Salim, H. M., Loke, S. ve Khalid, K. (2011). Demographic profiling on job satisfaction in Malaysian utility sector. International Journal of Academic Research, 3(4), 192-198.

Kılıç, S. ve Gümüşeli, A. İ. (2010). İstanbul ili vakıf üniversitelerine bağlı meslek yüksekokullarında görevli öğretim elemanlarının iş doyum düzeyleri. İstanbul Üniversitesi Issletme Fakültesi Dergisi, 39(2), 290-309.

Kılıç, S., Tanrıkulu, T. ve Uğur, H. (2013). Devlet okullarında görev yapan öğretmenlerin iş doyumu ve sosyal karşılaştırma düzeylerinin incelenmesi. International Journal of Human Sciences, 10(1), 760-779.

Korkki, P. (2012, 28 Ocak). Building a bridge to a lonely colleague. The New York Times. Erişim adresi: http://www.nytimes.com/

Lam, W. L. ve Lau, C. D. (2012). Feeling lonely at work: Investigating the consequences of unsatisfactory workplace relationships. The International Journal of Human Resurce Management, 23(20), 4265-4282.

Lopata, H. Z. (1969). Loneliness: forms and components. Social Problems, 17(2), 248-262.

Martin, U. ve Schinke, P. S. (1998). Organizational and individual factors influencing job satisfaction and burnout of mental health workers. Social Work in Health Care, 28(2), 51-62.

McCann, D. R. (2001). A study of job satisfaction among directors of classified personnel in merit (civil service) systems in California public school districts, county offices of education, and community college districts (Doktora tezi). Berne Üniversitesi, PA, ABD.

Mercan, N., Oyur, E., Alamur, B., Gül, S. ve Bengül, S. (2012). İşyeri yalnızlığ1 ve sosyal fobi arasındaki ilişkiye yönelik bir araştırma. Organizasyon ve Yönetim Bilimleri Dergisi, 4(1), 213-226.

Mertoğlu, S. (2013). Gülhane Askeri T⿰р Fakültesi Eğitim Hastanesi'nde çalışan sağllk personelinin tükenmişlik ve iş doyumu düreylerini etkileyen etmenlerin incelenmesi (Yüksek Lisans Tezi). Hacettepe Üniversitesi, Ankara.

Oğuz, E. ve Kalkan, M. (2014). Öğretmenlerin iş yaşamında algıladıkları yalnızlık ile sosyal destek düzeyleri arasındaki ilişki. İlkögretim Online, 13(3), 787-795.

Ölçüm, D. (2015). Okul yöneticilerinin karar verme stillerinin ögretmenlerin iș doyumuna etkisi (Sakarya ili örneği) (Yüksek Lisans Tezi). Sakarya Üniversitesi, Sakarya.

Parsak, G. (2010). Örgütlerde yabancılaşma ve iş tatmini ilişkisi: Cukurova Üniversitesi çallşanlar üzerinde bir uygulama (Yüksek Lisans Tezi). Çukurova Üniversitesi, Adana.

Peng, J., Chen, Y., Xia, Y. ve Ran, Y. (2017). Workplace loneliness, leader-member exchange and creativity: The cross-level moderating role of leader compassion. Personality and Individual Differences, 104, 510-515.

Peplau, L. A. (1985). Loneliness research: Basic concepts and findings. İçinde I. G. Sarason ve B. R. Sarason (Edt.). Social Support: Theory, Research and Applications (ss. 268-286) içinde. Washington: University of Washington, USA.

Peplau, L. A. ve Perlman, D. (1982). Perspectives on loneliness. Içinde L. A. Peplau ve D. Perlman (Edt.). Loneliness: A Sourcebook of Current Theory, Research and Therapy (ss. 1-18) New York: A Wiley Interscience Publication. 
Perlman, D. ve Peplau, L. A. (1981). Toward a social psychology of loneliness. İçinde S. Duck ve R. Gilmour (Edt.). Personal Relationships in Disorder (ss. 31-56). London: Academic Press.

Rokach, A. ve Brock, H. (1998). Coping with loneliness. The Journal of Psychology, 132(1), 107-127.

Russel, D., Peplau, L. A. ve Ferguson, M. L. (1978). Developing a measure of loneliness. Journal of Personality Assessment, 42(3), 290-294.

Sarıboğa, M. (2017). Nepotiẓmin örgütsel bağhllke ve iş doyumuna etkisi ve otel çalısanlar üzerine bir araştırma (Yüksek Lisans Tezi). Doğuş Üniversitesi, İstanbul.

Saygı1l, M. ve Çelik, Y. (2011). Hastane çalışanlarının çalışma ortamlarına ilişkin algıları ile iş doyumu düzeyleri arasındaki ilişkinin değerlendirilmesi. Hacettepe Sağhlk İdaresi Dergisi, 14(1), 39-71.

Subulan, E. (2015). Örgütlerde yaşanan kişilerarası çatıs̆malarn çalışanlarn iş doyumu üæerine etkisi ve bir araștırma (Yüksek Lisans Tezi). Dokuz Eylül Üniversitesi, İzmir.

Şangar, Z. (2016). Is doyumu ve yaşam kalitesi: Akademik personel üzerinde bir çalışma (Yüksek Lisans Tezi). Osmangazi Üniversitesi, Eskişehir.

Şişman, M. ve Turan, S. (2004). Bazı örgütsel değişkenler açısından çalışanların iş doyumu ve sosyal-duygusal yalnızlık düzeyleri. Osman Gazi Üniversitesi Sosyal Bilimler Dergisi, 5(1), 117-128.

Tabachnick, B. G. ve Fidell, L. S. (2013). Using multivariate statistics (sixth ed.). Boston: Pearson.

Tabancalı, E. (2016). The relationship between teachers' job satisfaction and loneliness at the workplace. Eurasian Journal of Educational Research, 66, 263-280.

Tabancalı, E. ve Korumaz, M. (2014). İl eğitim denetmenlerinin iş yerinde yalnızlıklarının incelenmesi. Akedeniz. Ĕgitim Araştormalar Dergisi, (15), 31-40.

Ünverdi, D. (2016). Okul yöneticilerinin etik liderlik davranışlarmm öğretmenlerin iş doyumu ile ilişkisi (Yüksek Lisans Tezi). Zirve Üniversitesi, Gaziantep.

Weiss, D. J., Dawis, R. V., England, G. W. ve Lofquist, L. H. (1967). Manual for the Minnesota Satisfaction Questionnaire. Minnesota studies in vocational rehabilitation: xxii. Washington DC, US: University of Minnesota.

Wright, S. L. (2005). Loneliness in the workplace (Doktora Tezi). University of Canterbury, Christchurch.

Wright, S. L., Burt, C. D. B. ve Strongman, K. T. (2006). Loneliness in the workplace construct definition and scale development. New Zealand Journal of Psychology, 35(2), 59-68.

Wright, S. L. (2007). The experience of loneliness in organizational settings. İçinde R. L. Morrison, ve S. L. Wright (Edt.). Friends and Enemies in Organizations: A Work Psychology Perspective (ss. 10-31). Londra: Palgrave Macmillan.

Yakut, S. (2016). Öğretmenlerde yabancılaşma, yalnı̨lı ve dindarllk ilişkisi: Polath örneği (Yüksek Lisans Tezi). Süleyman Demirel Üniversitesi, Isparta.

Yıldız, Ö. (2010). İzmir il merkezindeki mesleki ve teknik liselerde çalssan öğretmenlerin iş doyum düzeyleri (Yüksek Lisans Tezi). Dokuz Eylül Ǘniversitesi, İzmir.

Yılmaz, E. ve Aslan, H. (2013). Öğretmenlerin iş yerindeki yalnızlıkları ve yaşam doyumları arasındaki ilişkinin incelenmesi. Pegem Journal of Education \& Instruction, 3(3), 59-69.

\section{EXTENDED ABSTRACT}

In this study, the relationship between employees' sense of loneliness and organizational job satisfaction is discussed. Loneliness can be an indicator of organizational problems as well as individual for a social entity. Failure to establish healthy communication channels among employees is one of the important reasons why employees experience a sense of loneliness. Although the socialization are examined theoretically, it is not possible to distinguish between loneliness in daily life and loneliness in the workplace. Even if they establish healthy and satisfying social relationships during the times when employees are out of working time, they may feel lonely in the workplace. In this respect, loneliness in the workplace is one of the emotional situations experienced by the employee while working.

Job satisfaction refers to the level of meeting employees' expectations from working life. Job satisfaction shows the level of satisfaction related to the work done by the individual, where psychological, physiological and environmental factors are determinant (Şişman \& Turan, 2004). Job satisfaction varies continuously according to time and individuals. Job satisfaction is influenced by individual and organizational factors such as the age of the individual, educational status, marital status, title, seniority, or the nature of the job studied, the form of management, the working environment and the remuneration policy.

Loneliness is a subjective life situation arising from the lack of social relations. Loneliness in working life is about social relations in organizations. Universities are organizations where social relations come to the fore. The phenomenon of loneliness in working life can reduce the quality of life of those who work at an individual level, as well as indirectly affect the quality of education provided at universities. Determining the loneliness of administrative employees in public institutions such as universities is a requirement in this context. 
This research aims to determine the relationship between loneliness and job satisfaction levels in the working life of administrative staff working in Mersin University. In this regard, the study was designed in accordance with the relational screening model. In the study, the relationship between the level of loneliness experienced by administrative workers in working life and job satisfaction was determined based on quantitative descriptions. The working group of the research consists of 279 administrative staff in the general administrative services class working at Mersin University. Data collection tool consisting of three parts. In the first part, it consists of the expressions of "personal information" aiming to determine the individual characteristics of the participants. In this section, items aiming to determine gender, age, seniority, educational status, marital status, title and staff unit are included.

In order to determine the loneliness levels of the participants in the working life, the "Loneliness in Business Scale" [ISS] was developed by Wright, Burt and Strongman (2006) and adapted to Turkish by Doğan, Çetin and Sungur (2009). The "Minnesota Job Satisfaction Scale" (MIDS) developed by Weiss, Dawis, England and Lofquist (1967) and adapted to Turkish by Baycan (1985) was used to determine the opinions of the participants on job satisfaction. In the research, frequency, percentage and average statistics, which are descriptive analysis techniques, were used to determine the opinions of the participants about job satisfaction and loneliness in business life.

Whether the opinions of the participants differed according to gender and marital status was determined by the t-test technique, and by variance analysis techniques whether they differed according to their seniority and educational status. The correlation analysis technique between the job satisfaction scale scores of the participants and the loneliness scale scores in the working life was also used, and regression analysis technique was used to determine the level of loneliness levels of the participants in the work life. The interpretation of the findings was based on the $\mathrm{p}<.05$ significance level.

Job satisfaction levels of the participants are medium and above. Participants consider doing things for others and doing things that are not contrary to their conscience in terms of job satisfaction. The opinions of the participants about the overall and sub-dimensions of job satisfaction do not differ significantly according to the gender variable. Job satisfaction levels of female and male employees are close to each other. Participants' opinions on job satisfaction differ significantly according to their seniority. Participants with more than 20 years of seniority have higher job satisfaction levels than participants with 0-9 years of seniority, which can be counted at the beginning of their professional life. Participants' opinions on job satisfaction differ significantly according to their positions. Job satisfaction levels of the participants in the supervisor position differ significantly from the participants in the civil servant position, and the job satisfaction of the supervisors is higher. In other words, there is a close relationship between job satisfaction and professional career steps, and superiority is in favor of superiors in this relationship.

The opinions of the participants in overall and sub-dimensions of job satisfaction differ significantly according to their marital status. Married participants' overall satisfaction, external satisfaction, and overall job satisfaction scores are higher than single participants. The fact that the opinions of the participants about the emotional deprivation sub-dimension of the ISSL at the levels of "disagree" and "stay indecisive" show that Mersin University administrative staff do not experience significant emotional deprivation.

Opinions of the participants on all of the sub-dimensions and sub-dimensions did not differ significantly according to gender. Opinions of the participants about the overall SUM and sub-dimensions do not differ significantly according to their seniority years. Opinions of the participants about the overall SUM and emotional deprivation sub-dimension differ significantly according to the position studied. Accordingly, the participants who work at the supervisor level in the chief and above staff experience less emotional loneliness than the participants at the lower level. In other words, those who work as civil servants are more emotionally lonely, although they are more numerous than their managers.

On the other hand, the opinions on the sub-dimension of IYYÖ social friendship do not differ significantly. In other words, the fact that the participants have the status of supervisors or officers does not differentiate their views on social friendship. Opinions of the participants on the emotional deprivation of SES do not differ significantly according to their marital status. In other words, married and single participants experience similar situations in terms of emotional deprivation. However, the opinions of the participants on the overall SRS and social friendship sub-dimension differ significantly depending on the marital status. Accordingly, married workers experience less loneliness in business life 
and social friendship than singles. There is a negative relationship between the job satisfaction of the participants and their loneliness in working life. Accordingly, as the level of loneliness in the working life of the employees increases, their job satisfaction decreases. Loneliness levels of the participants are a significant predictor of their job satisfaction levels. Accordingly, $34.4 \%$ of the variance related to job satisfaction is explained by the loneliness scale in the working life and the variables of gender, seniority, title, age, marital status and staff unit. 